\section{Things that go bump in the light. The differential diagnosis of posterior uveal melanomas}

Eye (2002) 16, 325-346. doi:10.1038/ sj.eye. 6700117

\section{Introduction}

The role of the ocular oncologist is two-fold: he must establish the correct diagnosis and then institute the appropriate therapy, if required. Prior to the establishment of ocular oncology as a speciality in its own right, the majority of patients with a uveal melanoma were treated by enucleation. It was recognised that inaccuracies in diagnosis occurred, but the frequency of these errors was not fully appreciated until 1964 when Ferry studied a series of 7877 enucleation specimens. He found that out of 529 eyes clinically diagnosed as containing a melanoma, 100 harboured a lesion other than a malignant melanoma. ${ }^{1}$ Subsequent studies have shown a progressive improvement in the accuracy with which these tumours can be recognised. Shields and McDonald in 1974 found the misdiagnosis rate to have fallen to $1.9 \% .^{2}$ More recent studies demonstrate a further improvement with the COMS study group in 1990 reporting an incidence of only $0.48 \%{ }^{3}$ These improvements in the accuracy of diagnosis can be attributed to an increased awareness of lesions that may simulate malignant melanomas, improved diagnostic techniques and increased referral to units specializing in the treatment of ocular tumours.

Many lesions that are mistaken for melanomas are non-malignant, nevertheless, they may pose a serious threat to vision and require prompt treatment in their own right. Others may be benign but have the potential to undergo malignant transformation and occasionally a benign lesion may be the harbinger of a neoplasm elsewhere.
IG Rennie

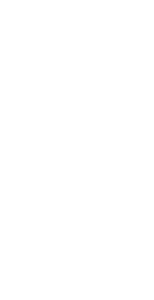

The list of lesions that may simulate a malignant melanoma is extensive; Shields et $a l^{4}$ in a study of 400 patients referred to their service with a pseudomelanoma found these to encompass 40 different conditions at final diagnosis. Naturally, some lesions are mistaken for melanomas more frequently than others. In this study over one quarter of the patients referred with a diagnosis of a presumed melanoma were subsequently found to have a suspicious naevus. We have recently examined the records of patients referred to the ocular oncology service in Sheffield with the diagnosis of a malignant melanoma. Patients with iris lesions or where the diagnosis of a melanoma was not mentioned in the referral letter were excluded. During the period 1985-1999 1154 patients were referred with a presumed melanoma and of these the diagnosis was confirmed in 936 cases $(81 \%)$. In 218 patients $(19 \%)$ a different final diagnosis was made. Over half of the patients with pseudomelanomas (58\%) were diagnosed as having an indeterminate melanocytic lesion (IML). This diagnosis will be discussed in detail later. Choroidal naevi $(8.7 \%)$, haemangiomas $(6.9 \%)$, and choroidal neovascularization (macula and eccentric disciforms) (5\%) were the next most frequently misdiagnosed lesions. In all, 12 different conditions were found to have simulated choroidal melanoma (see Table 1)

(manuscript in preparation).

Pseudomelanomas can be divided into pigmented and non-pigmented lesions. Pigmented lesions may be melanocytic in origin or derived from the iris, ciliary body or retinal pigment epithelium (Figure 1). Nonpigmented lesions are more diverse in nature, but can be divided into neoplastic, inflammatory or reactive, and vascular lesions (see Figure 2).
University of Sheffield Sheffield, UK

Correspondence: Prof IG Rennie Floor O Royal Hallamshire Hospital Sheffield SIO 2JF, UK Tel: 01142712902 Fax: 01142766381 E-mail: i.g.rennie@ shef.ac.uk 


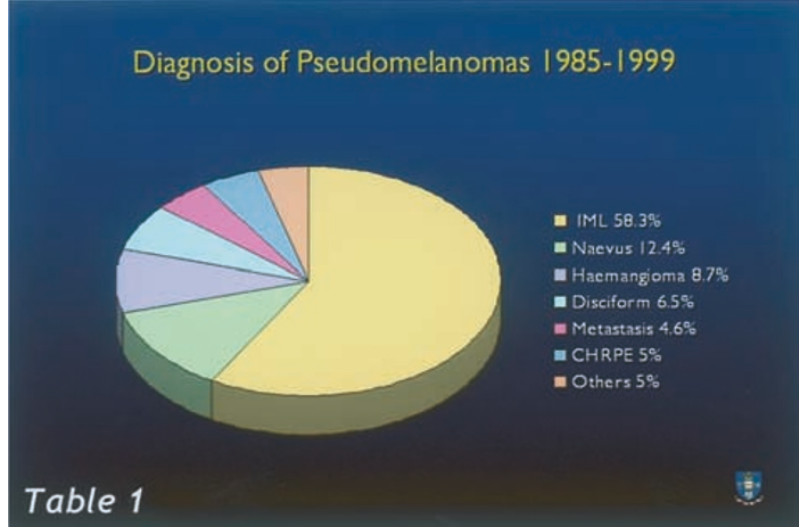

Table 1 Diagnosis of pseudomelanomas 1985-1999.

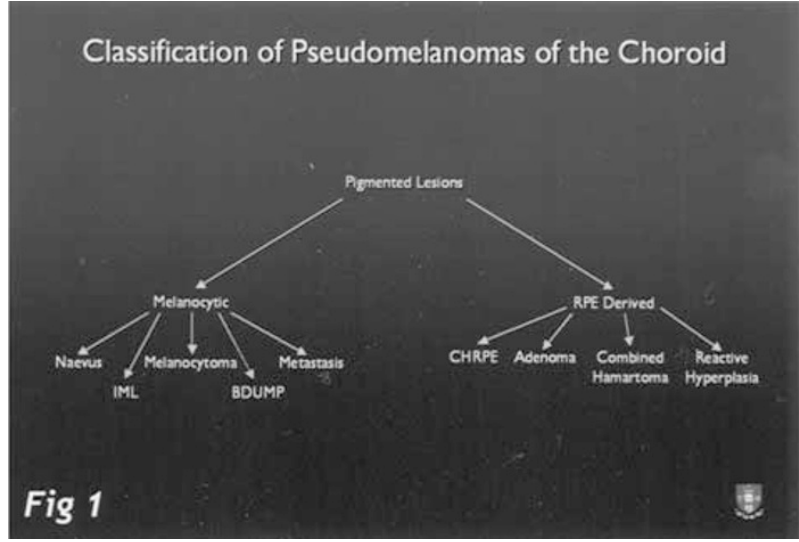

Figure 1 Classification of pseudomelanomas of the choroid (pigmented lesions).

\section{Pigmented lesions}

\section{Melanocytic origin}

Naevi The commonest pigmented intraocular lesion is the naevus. Estimates of their frequency vary from 1 to $9 \%$ of the population. In 1998 Sumich $^{5}$ et al examined a total of 3654 individuals aged 49-79 years using six standard field fundus photography and found that choroidal naevi were present in $6.5 \%$ of the study cohort. Correction of the data to account for possible naevi missed by the photography gave prevalence rates of $8.9 \%$ for women and $8.3 \%$ for men. These figures agree closely with post-mortem studies, which found that almost $9 \%$ of the eyes examined contained a nevus of either the ciliary body or choroid. ${ }^{6}$

Previous clinical studies have found a lower incidence. Ganley and Comstock ${ }^{7}$ found an incidence of $3.1 \%$ in a sample of individuals aged over 30 years. Earlier clinical studies have found an incidence of
Classification of Pseudomelanomas of the Choroid

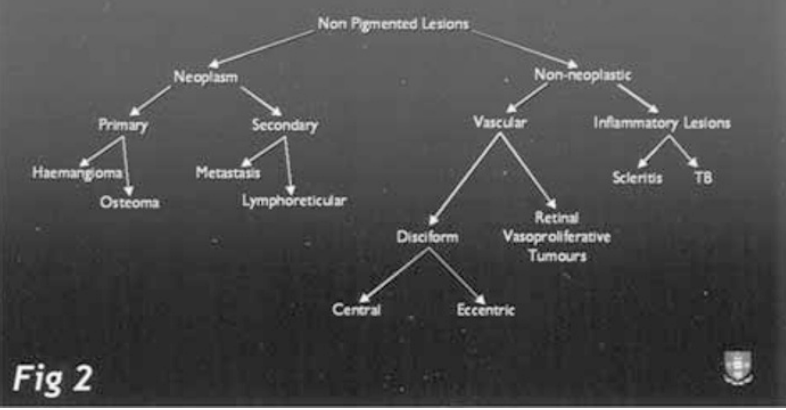

Figure 2 Classification of pseudomelanomas of the choroid (non pigmented lesions).

approximately $1 \% .^{8}$ Whilst this variation may reflect sampling errors or improvements in clinical examination (for example the use of indirect ophthalmoscopy or fundus photography), it may also reflect the importance of age on the development of naevi. It is well recognised that choroidal naevi are uncommon in children and adolescents ${ }^{9}$ and are rarely observed in neonates. Naevi probably develop from nests of cells that are present at birth and then either proliferate or pigment at puberty. Tumour growth, although often taken as a sign of malignancy, may be observed in histologically proven benign nevi. MacIlwaine et $a l^{10}$ reported a case of a raised pigmented choroidal lesion that enlarged over a 6.5year period and after enucleation was found to be a choroidal naevus.

Clinically, the typical choroidal naevus is a flat or minimally elevated pigmented lesion in the post equatorial choroid. The majority are brown to slategrey in colour and range in size from $0.5-4.5 \mathrm{~mm}$ in diameter. ${ }^{5}$ The edges of the lesion may be distinct or blend slightly into the surrounding choroid. The surface is usually uniform in colour, although retinal pigment epithelial changes are common. ${ }^{11}$ Drusen may be observed on the surface of naevi, particularly in the central portions of the larger lesions (Figure 3). Occasionally, large solitary drusen are present on the surface of the naevus. ${ }^{12}$

Whilst many naevi have a typical appearance, several clinical variants can be recognised; partial or even totally amelanotic nevi occur. One rather peculiar variant is the halo naevus where there is a yellowish ring surrounding the lesion. Interestingly, this latter variant has been observed in a patient with vitiligo. ${ }^{13}$ Abnormalities of visual function have in the past been taken as an indication that a pigmented fundal lesion is malignant and whilst visual symptoms undoubtedly 
occur more frequently in malignant pigmented lesions, they may also be associated with benign naevi. Asymptomatic scotomas corresponding to the anatomical sites of the lesions can be demonstrated using careful perimetry. ${ }^{14-16}$ Reduced central visual acuity may be present if the naevus is subfoveal. ${ }^{17}$ Presumably these abnormalities of visual function are attributable to photoreceptor dysfunction either in the absence of or secondary to retinal pigment epithelial degeneration. Visual loss can also result from the development of either a serous retinal detachment or choroidal neovascularization. ${ }^{17-19}$ Serous retinal detachments can arise as a direct result of a retinal pigment epithelial disturbance, or secondary to choroidal neovascularization. Similarly, choroidal neovascularization can lead to visual loss as a result of subretinal haemorrhage and scarring or serous retinal detachment.

Indeterminate melanocytic lesions The majority of melanocytic lesions of the choroid are either benign naevi or malignant melanomas; they are a group of lesions that clearly do not fit comfortably in either category. Such lesions are larger than normal naevi and often significantly elevated, and yet if merely observed, remain indolent for many years. I use the term indeterminate melanocytic lesions (IMLs) to describe such lesions. As such they probably correspond to lesions described as low-grade melanomas or suspicious naevi. Typically, IMLs appear as pigmented, elevated lesions in the mid-peripheral choroid. They vary considerably in size with the largest attaining 3-4 $\mathrm{mm}$ in thickness. The surface of the lesion may at least in part be covered by whitish tissue giving the lesion a sclerotic appearance. Drusen frequently cover the lesion; but orange pigment is invariably absent. Alteration of the overlying retinal pigment epithelium is often present and usually appears as a pigmentary clumping resembling the bone spicule appearances seen in retinitis pigmentosa. Whilst these pigmentary changes may cover the entire surface of the lesion, more often, they are located towards the anterior portion of the lesion (Figure 4). It is possible that these pigment epithelial changes have arisen as a result of a prior accumulation of subretinal fluid, which has subsequently reabsorbed. In the course of my practice, I have observed a number of such lesions; the majority of which have shown no discernible growth over a number of years. Whilst it appears that these lesions are melanocytic in lineage, in the absence of any histological examination, one can only speculate as to their precise nature. Clearly, their size and appearance suggest they have arisen by virtue of some neoplastic process; but the fact that their growth appears to dramatically slow down or stop mitigates against them having the unrestrained growth of a malignant lesion. It is now recognized that malignant neoplasms arise by virtue of genetic mutations in the cell that in turn leads to a loss of regulation in cell cycling, leading to unrestrained growth. Furthermore, it is apparent from studies of other malignancies that tumours do not develop because of a single genetic mutation; but rather as a result of a series of, often sequential, changes which ultimately result in a lesion with unrestrained growth, invasiveness and metastatic capability. Indeed, studies in our own laboratory and those of others have identified specific chromosome alterations in uveal melanomas. ${ }^{20-23}$ Moreover, it would appear that some of these changes (notably alterations of 3 and 8) correlate strongly with prognosis, ${ }^{24-26}$ suggesting that these particular changes are relatively late changes in the progression to a metastatic phenotype. Thus if one accepts that uveal melanomas arise as a result of a sequence of several genetic mutations, then it is possible to speculate that some early genetic mutations may have occurred in IMLs; but that the process has arrested before a complete malignant phenotype has developed. Whilst this possible hypothesis remains unproven, it is at least in part supported by clinical observation; for although the majority of such lesions are indolent, I have observed growth in at least two tumours (in each instance manifest by a small herniation through Bruch's membrane) after many years of apparent dormancy (Figure 5): suggesting the eventual acquisition of further mutations which in turn, have led to the development of an invasive phenotype. In view of the fact that most lesions remain unchanged over many years I advocate that such lesions merely be observed.

Melanocytomas The term melanocytoma was first used by Zimmerman and Garron ${ }^{27}$ to describe a deeply pigmented benign tumour arising from the optic disc. Prior to this, such lesions were thought to be peripapillary melanomas invading the optic nerve head. Melanocytomas are in fact merely a form of naevus which are characterised clinically by their dark brown or black colouration and histologically by the presence of rather plump, round to oval deeply pigmented cells with small round nuclei which lack significant pleomorphism. Since their original description, similar tumours have been described in all parts of the uveal tract. Melanocytomas occur more frequently in non-white races ${ }^{27,28}$ and may be slightly more common in females.

Melanocytomas of the optic disc typically appear as an elevated dark brown or black lesion, which 

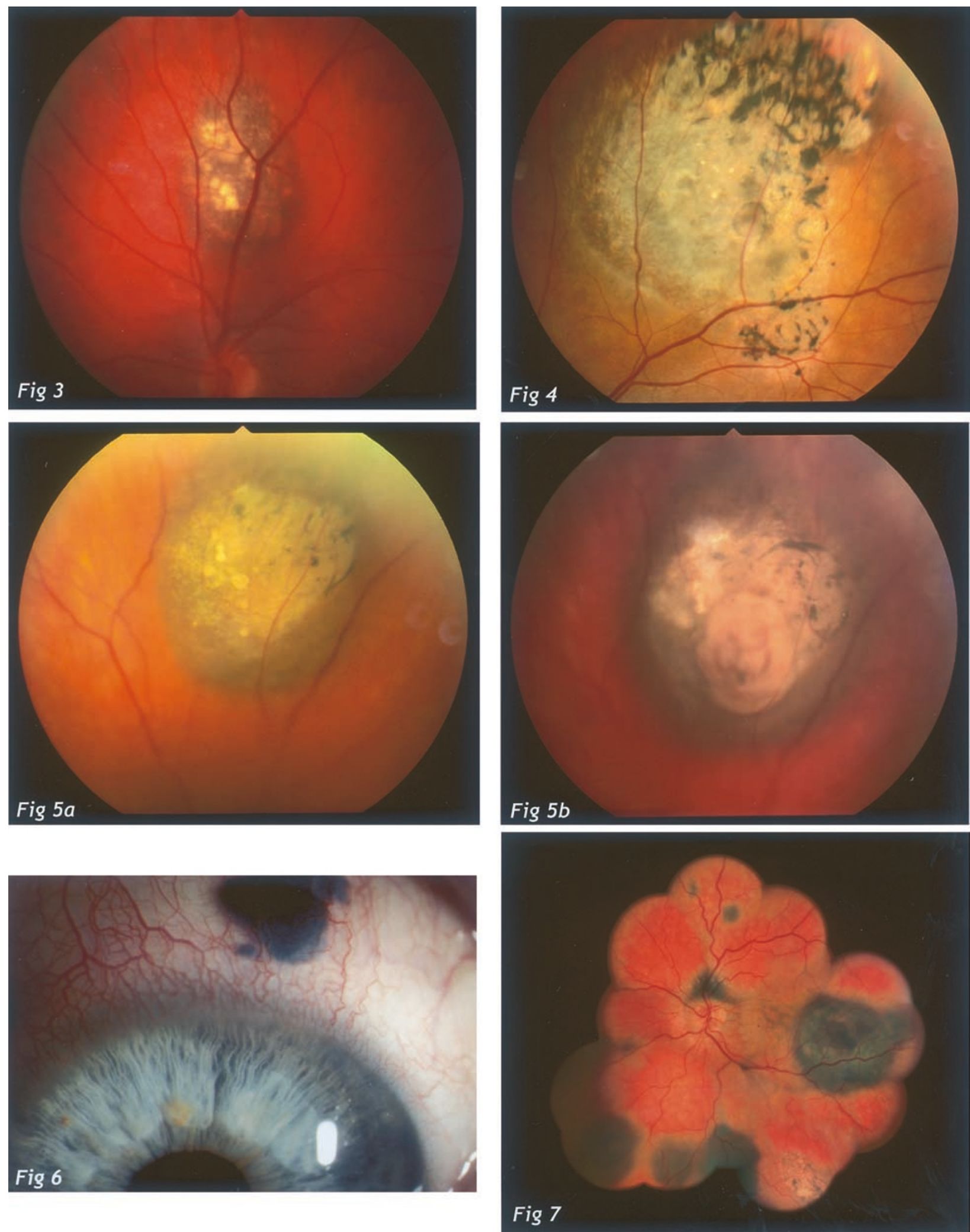
occupies part or occasionally the entire optic disc. Melanocytomas usually extend over the edge of the optic disc and in about half the cases appear to have an associated contiguous choroidal naevus, ${ }^{28}$ which is merely an extension of the melanocytoma beneath the juxtapapillary retinal pigment epithelium. Whilst most melanocytomas of the optic disc are asymptomatic, disturbances of visual function have been reported; the commonest being a defect in the visual field which can be either an enlarged blind spot or a scotoma

corresponding to a retinal nerve fibre bundle defect. ${ }^{29-31}$ Sporadic cases of sudden, profound loss of vision due to retinal vascular occlusion, ${ }^{32,33}$ ischaemic optic neuropathy $^{30}$ or neuroretinitis ${ }^{34}$ have been reported. Spontaneous necrosis of optic disc melanocytomas ${ }^{32,35}$ can occur and this may be complicated by secondary (neovascular) glaucoma. ${ }^{36}$ Rarely, seeding of the vitreous with pigment particles has been described; in one case this was associated with migration of the particles into the anterior segment. ${ }^{37-39}$ Although benign, optic disc melanocytomas may enlarge in size. Joffe et $a l^{28}$ evaluated 27 cases of optic disc melanocytoma and an increase in size in four (15\%) cases.

Melanocytomas of the uveal tract are very uncommon. The ciliary body is probably the most common non-peripapillary location. ${ }^{40}$ These lesions are densely pigmented and may simulate a ciliary body melanoma. Extra-ocular extension of these tumours can be observed producing a deeply pigmented episcleral mass $^{41}$ (Figure 6). I have observed three such cases and in each instance the accompanying ciliary body tumour was small in size. In general, ciliary body melanomas only develop extrascleral extension when they have attained a large size. Thus, the diagnosis of a ciliary body melanocytoma should be considered in the presence of a small, pigmented ciliary body tumour with apparent extrascleral extension. Pigment dispersion and secondary glaucoma can develop in association with ciliary body melanocytomas. ${ }^{42,43}$

Once the basic pathology of melanocytomas was established, they were considered to have no malignant potential. Subsequent reports have shown that these tumours can, in rare instances, undergo malignant

Figures 3-7 Figure 3 A choroidal naevus. Note the large drusen on the surface of the lesion. Figure 4 An indeterminate melanocytic lesion. There are characteristic retinal pigmentary changes at the periphery of the lesion. Figure 5 (a) An indeterminate melanocytic lesion. (b) The same lesion approximately 12 years later. The lesion has now started to grow and a small nodule of tumour tissue has herniated through Bruch's membrane. Figure 6 A melanocytoma of the ciliary body with extra-scleral extension. Figure 7 Bilateral diffuse uveal melanocytic proliferation. transformation ${ }^{44-50}$ and for this reason periodic observation of such lesions is mandatory.

\section{Bilateral diffuse uveal melanocytic proliferation}

(BDUMP) Bilateral diffuse uveal melanocytic proliferation (BDUMP) is a curious paraneoplastic syndrome occurring usually in patients with a systemic, often occult, carcinoma. ${ }^{51}$ The first reported case was probably described by Machemer ${ }^{52}$ in 1966 who reported the development of bilateral diffuse malignant melanomas of the whole uvea in a patient with an abdominal tumour that was believed to be a primary pancreatic carcinoma. In 1980 Ryll et al $l^{53}$ reported a case of a 64-yr-old male who presented with bilateral visual loss associated with multiple darkly pigmented lesions scattered throughout the choroid of both eyes and was subsequently found to have a primary bronchial carcinoma. Progressive enlargement of the lesions occurred until his death 15 months later. Histological examination of the eyes showed multiple discrete benign melanocytomas within a naevus involving the entire uveal tract. Barr and Zimmerman in $1982^{54}$ reported four cases of bilateral diffuse melanocytic tumours associated with a systemic neoplasm and suggested this constellation of findings represented a new syndrome. Since then, sporadic reports have appeared in the literature confirming this phenomena as a rare, but definite clinical entity. ${ }^{51,55-67}$

Gass $^{51}$ considered the syndrome clinically to have five cardinal features that accompanied the visual loss. These are: multiple round or oval, subtle red patches at the level of the retinal pigment epithelium in the posterior fundus; a striking pattern of multifocal areas of hyperfluorescence corresponding to these patches on angiography; the development of multiple slightly elevated, pigmented and non-pigmented melanocytic tumours (Figure 7) together with diffuse thickening of the entire uveal tract; exudative retinal detachment; and rapidly progressive cataracts. The retinal pigment epithelial changes are usually the first to appear and usually remain visible after the other retinal signs have appeared. Other features include conjuctival hyperaemia and/or dilated episcleral vessels, ${ }^{51,54,55,62,65,67}$ shallowing of the anterior chamber ${ }^{57}$ and ciliary body cysts, ${ }^{55}$ iridodenesis, ${ }^{56}$ uveitis $^{51}$ and raised intraocular pressure. ${ }^{51,54,57,60,62,67}$ Extrascleral extension of the melanocytic lesion through the emissary channels into the subconjunctival space has also been observed. ${ }^{54,66}$ Electroretinographic studies have demonstrated a variety of abnormalities including unrecordable electroretinograms or a marked reduction in both cone and rod function. 56,58,60,62 Two further patients were found to have normal or slightly reduced 
cone function with a severe reduction in rod function. ${ }^{51,65}$

In the majority of reported cases there has been an associated systemic malignancy which may have been diagnosed prior to the eye condition or which is found at the time of diagnosis as a result of a systemic examination. Occasionally, BDUMP may precede the diagnosis or occur in the abscence of a systemic malignancy. ${ }^{51,62}$ BDUMP may arise in association with a variety of malignancies, however, gynaecological neoplasms including: ovary (in particular), $51,56,61,63,68$ cervix $^{51}$ and uterus ${ }^{60,67}$ predominate. Other primary sites include: pancreas, ${ }^{51,52,54}$ lung, ${ }^{53,54,57,66}$ gall-bladder $^{58}$ and bowel. ${ }^{54,64}$ Recently, two cases of extraocular pigmentation associated with BDUMP have been reported. Gass and Glatzer ${ }^{64}$ documented a case of a 74-year-old male with BDUMP related to an occult carcinoma of the colon who developed pigmentation of the mouth and penis reminiscent of the Peutz-Jeghers syndrome. More recently, Mooy et al ${ }^{66}$ have described a similar case where multiple pigmented lesions developed on the penis, oral mucosa and skin of an 82year-old man with BDUMP secondary to a bronchial carcinoma.

Despite the relative rarity of this condition, there have been a number of histological studies of the affected ocular tissues. ${ }^{51-54,56-62,65,66,69}$ The most consistent reported features are a diffuse thickening of the choroid with benign appearing naevus or spindle cells, ${ }^{54}$ associated with discrete elevated lesions that may resemble melanocytomas..$^{53}$ Focal necrosis and infiltration of scleral channels are frequently observed. Although mitotic figures are uncommon, foci of epithelioid cells may be present. In such instances, the appearance may be indistinguishable from a diffuse melanoma of the uvea. Opinion is divided as to the true pathological nature of this condition; some consider it to be a benign hyperplasia of uveal melanocytes, whilst others point to the presence of epithelioid cells and scleral 'invasion' as indicative of a true malignant neoplasm. To date, there have been no reported cases of metastases from the ocular lesions in a case of BDUMP, however, as many individuals rapidly succumb to their systemic malignancy, this does not negate the possibility that malignant transformation has occurred. In a recent immunohistochemical study, p53 protein expression was investigated in eight eyes from four cases of BDUMP. ${ }^{69}$ The p53 protein is a phosphoprotein that occurs normally in cells and in its natural form it has a regulatory effect on cell proliferation. Under normal circumstances p53 is produced in quantities that are too small to be detected by immuno-histochemistry. Mutations of p53 occur which result in the production of a defective protein that has little or no regulatory function. This protein may accumulate in the cell and be detectable by immuno-histochemistry. Overexpression of mutant $\mathrm{p} 53$ protein has been described in many malignancies. Its role in uveal melanoma is unclear. Some studies have found a constant overexpression of ${ }^{70,71} \mathrm{p} 53$ whilst others have failed to do so. ${ }^{72}$ This study failed to detect $\mathrm{p} 53$ protein in any of the eight eyes with BDUMP suggesting that the proliferation of uveal melanocytes in BDUMP is not dependent on p53 over-expression.

The pathogenesis of BDUMP remains unclear. The frequent association of a systemic malignancy suggests that it is a paraneoplastic syndrome where uveal melanocytic cells proliferate in response to some as yet undefined cellular growth factor produced by the systemic tumour. ${ }^{51,65}$ The inability of the normal uveal melanocyte to proliferate has led some authors to suggest that eyes that develop BDUMP have congenital bilateral diffuse hypopigmented uveal melanocytic naevi, which proliferate when stimulated by the putative exogenous tumour related growth factor. ${ }^{51,53,65}$

Metastatic cutaneous melanomas When considering intraocular melanocytic tumours, one naturally thinks of the uveal melanocyte as the progenitor cell; however cutaneous malignant melanomas may metastasise to the eye. Recently, Shields et al ${ }^{73}$ reviewed 420 consecutive patients with uveal metastases; they found nine cases $(2 \%)$ of cutaneous melanoma metastatic to the eye. Gunduz et $a l^{74}$ in an extensive review of the literature found prior reports of 67 patients (82 eyes) of cutaneous melanoma metastatic to the eye. The choroid $(46 \%)$ was the most frequently involved tissue followed by the retina $(27 \%)$, iris $(23 \%)$, ciliary body $(22 \%)$, vitreous (18\%), optic disc (12\%) and anterior chamber (11\%). Multiple metastases involving more than one anatomical location were common. Despite the relative paucity of reported cases of clinically detectable intraocular metastatic cutaneous melanoma, occult metastases may be relatively common in cases of widespread generalised metastatic disease. In a series of 15 autopsy cases of patients with disseminated cutaneous melanoma, Fishman et $a l^{75}$ found evidence of microscopic deposits in five patients. The clinical appearances of intraocular metastases from cutaneous melanoma are very variable, and to a large extent, depend upon the precise location of the deposit. Solitary choroidal lesions may resemble primary uveal melanomas and may pose a diagnostic problem, particularly if they represent the first manifestation of disseminated disease. ${ }^{76}$ Intraocular metastatic cutaneous melanoma is somewhat unusual in that it frequently involves the ciliary body, ${ }^{77}$ retina ${ }^{78,79}$ and 
vitreous; ${ }^{74,79}$ the latter often in the absence of other tissue involvement. Recently, I have observed a case of bilateral vitreous deposits in the absence of any apparent retinal or uveal involvement (Figure 8).

The prognosis for patients who develop intraocular metastases from cutaneous melanoma is extremely poor with a reported median survival time of only 5 months. ${ }^{80}$

\section{Tumours and related lesions of the retinal pigment epithelium}

Congenital hypertrophy of the retinal pigment epithelium (CHRPE) Congenital hypertrophy of the retinal pigment epithelium (CHRPE) was first described in 1956 by Reese and Jones ${ }^{81}$ who called them benign melanomas of the RPE. Fortunately, Buettner replaced this confusing and contradictory term with congenital hypertrophy of the retinal pigment epithelium in $1974 .{ }^{82}$ CHRPE may occur in a solitary or multifocal forms and a specific variant is associated with Gardner's syndrome.

Solitary lesions are not uncommon and are still frequently mistaken for choroidal melanomas. They are flat or minimally elevated, well circumscribed, deeply pigmented lesions which may vary in size from less than $1 \mathrm{~mm}$ to occupy up to one quarter of the fundus. ${ }^{83-85}$ Typically, they are dark grey or black in colour and contain foci of depigmentation known as lacunae, which frequently enlarge with time $\mathrm{e}^{84,85}$ (Figure 9). A circumferential depigmented ring (marginal halo) has been observed in over $75 \%$ of cases. ${ }^{85}$ Fluorescein angiography shows a blocking of the normal choroidal fluorescence corresponding to the pigmented areas with hyperfluorescence corresponding to the lacunae and halo regions. ${ }^{84}$ Retinal vascular abnormalities overlying the lesion are common and include capillary loss, microaneurysmal capillary ectasias and rarely, retino-choroidal anastamoses. ${ }^{86,87}$ Traditionally, CHPREs were believed to be indolent lesions and that growth only occurred in exceptional cases. ${ }^{88,89}$ However, in a recent study of 35 patients with solitary CHRPEs, enlargement although often subtle, was observed in $74 \%$ of cases. ${ }^{85}$ To date, there have been no recorded cases of malignant transformation, Shields et $a l^{90}$ recently reported five cases of a nodular tumour arising from a pre-existing CHRPE lesion. The lesions ranged in colour from light brown to black and had minimally dilated, nontortuous feeder and drainage blood vessels supplying the tumour. Three cases were complicated by cystoid macular oedema and two had surface wrinkling of the retina. The authors speculate that these lesions probably represent examples of acquired adenomas arising from solitary CHRPEs.

A multifocal form of CHRPE may occur which is also known as 'bear track' retinopathy or congenital grouped pigmentation of the retina. Usually, there are numerous groups of slate-grey or black lesions of varying size that often appear to radiate away from the optic disc. These lesions are asymptomatic and are found during routine fundal examination.

Familial adenomatous polyposis is an autosomal dominant condition characterized by the development in childhood or adolescence of hundreds or thousands of colonic polyps. ${ }^{91}$ The condition has a prevalence of approximately 1:5000 in the general population. ${ }^{92}$ When the condition is associated with a variety of extra-colonic manifestations including osteomas, epidermal cysts, desmoid tumours and extracolonic cancers, the condition is termed Gardner's syndrome. ${ }^{91}$

In 1980 Blair and Trempe ${ }^{93}$ reported multiple foci of hypertrophy of the RPE in four members of a family with Gardner's syndrome. Since then, this ocular finding has been confirmed in a large number of affected families. ${ }^{94}$ Clinically, the fundal appearances are of bilateral, multiple, discrete pigmented lesions which are often oval in shape with a peculiar fishtailshaped hypopigmented change at one or both ends (Figure 10). ${ }^{84}$ These differ clinically from the solitary or bear track lesions, which are not associated with Gardner's syndrome. ${ }^{95}$

The gene responsible for familial polyposis coli is now known and has been mapped to chromosome 5q21-22. ${ }^{92}$ It has been called the adenomatous polyposis (APC) gene and consists of 15 exons and 14 introns spanning more than 100 kilobases. Over 700 mutations of the APC gene have been reported in FAP patients. ${ }^{96}$ There is a strong correlation between site of the mutation and clinical phenotype: patients with profuse adenomatous polyps (more than 5000) have APC mutations predominantly located between codons 1255 and 1467 in exon $15 .{ }^{97}$ Similarly, it has been found that patients with CHRPE occur almost exclusively with APC mutations between codons 312 1444. ${ }^{96-100}$ When mutations in the APC gene are located between codons 441-1444, the reported incidence of FAP patients with CHRPE lesions is over 95\%, whilst mutations between codons 312-428 result in a variable occurrence of CHRPE lesions. ${ }^{100}$ To date, the reason for the restriction of CHRPE-positive patients to a specific sub group of APC mutations remains unknown.

Tumours of the retinal pigment epithelium True tumours of the retinal pigment epithelium are extremely rare. Both adenomas and adenocarcinomas have been described; the distinction being based on the 
Fig 8
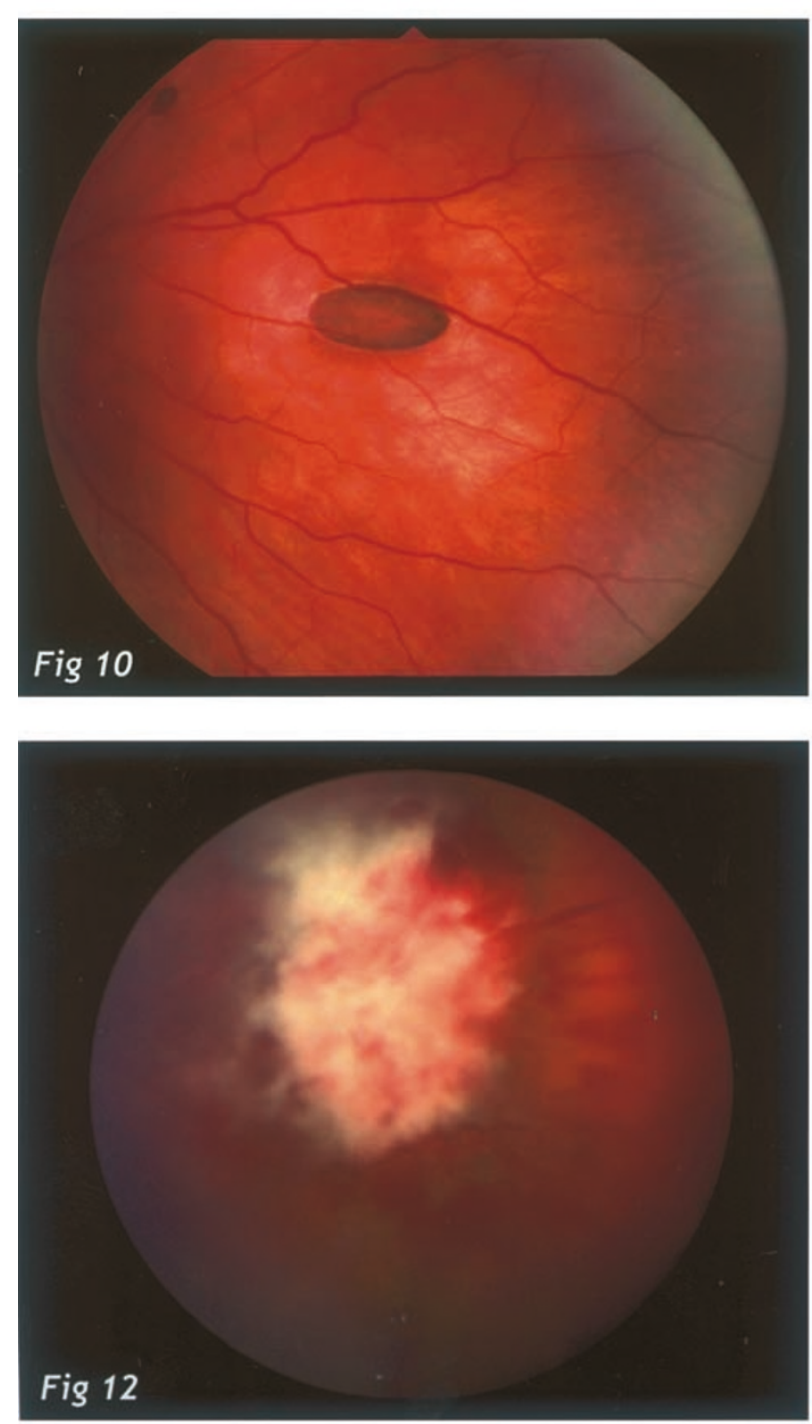
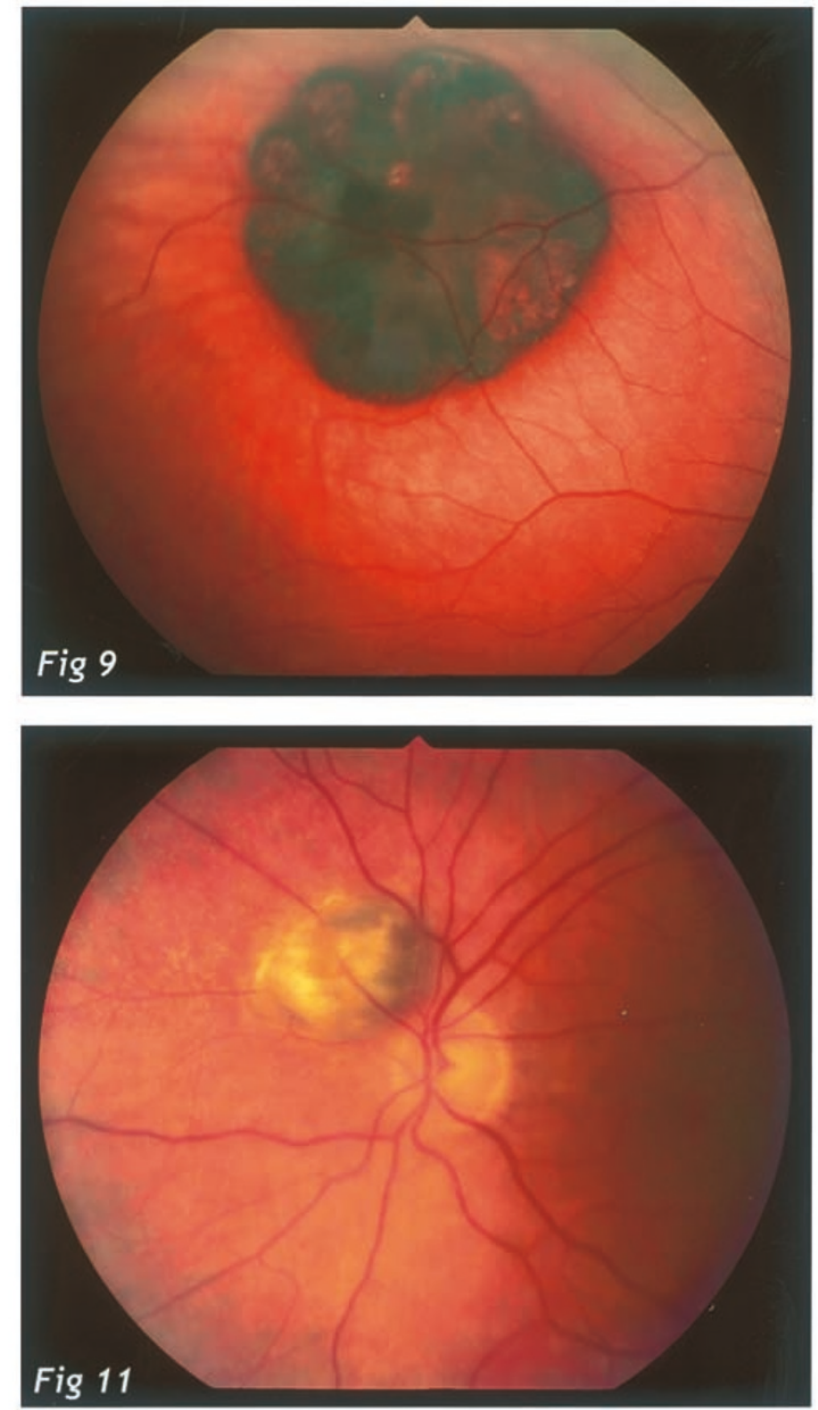

Fig 11

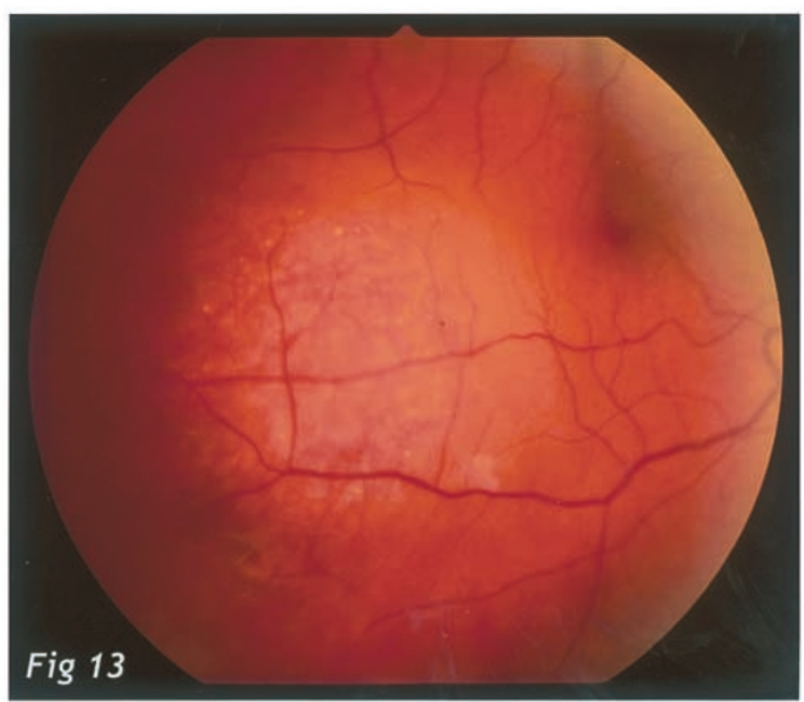


histological degree of nuclear pleomorphism and local invasiveness. ${ }^{101-103}$ The distinction may be academic for although cases of metastatic adenocarcinoma of the RPE have been reported in the literature prior to 1935, ${ }^{104-107}$ none have been reported since. Conceivably, this could be due to a misinterpretation of the histological findings by the early authors and indeed Tso et al in a review of pathological conditions of the RPE cast doubt on the validity of the original diagnosis in these cases. ${ }^{108}$ Even if the original diagnosis is accepted, as all of these four cases had extrascleral extension, the development of metastases may only occur in advanced cases when the sclera has been breached. Extrascleral extension has been reported only once in association with a posterior staphyloma ${ }^{109}$ in the more recently reported cases. ${ }^{101,102,110-114}$ Although the number of cases studied is relatively few, adenomas and adenocarcinomas appear to occur mainly in women. ${ }^{109}$

Clinically, adenomas and adenocarcinomas are indistinguishable and have frequently been mistaken for malignant melanomas. Ophthalmoscopically, neoplasms of the RPE are usually solitary, elevated dark brown or black lesions that appear to arise abruptly from the surrounding tissues. ${ }^{109}$ Invasion of the retina occurs frequently and may be associated with the presence of a prominent retinal artery and vein supplying and draining the tumour. ${ }^{109}$ Both intra and sub-retinal exudation can also occur leading to the development of an exudative retinal detachment. ${ }^{109}$ Rarely, these lesions may arise adjacent to or on the optic disc and simulate either a juxtapapillary melanoma or melanocytoma. ${ }^{115-117}$

Reactive hyperplasia of the retinal pigment epithelium The retinal pigment epithelium has a capacity to proliferate in response to certain stimuli. Hyperplasia or metaplasia may occur in response to trauma or inflammation producing a nodular mass. ${ }^{108}$ Such proliferations may be present in eyes with opaque media and be detected on ultrasonography or when the eye is removed because of pain or phthisis. Rarely, post-traumatic RPE hyperplasia can be seen in eyes with clear media. I have previously reported two cases of post-traumatic RPE hyperplasia that occurred in

Figures 8-13 Figure 8 Cutaneous melanoma metastatic to the vitreous. Figure 9 Congenital hypertrophy of the retinal pigment epithelium. Figure 10 Congenital hypertrophy of the retinal pigment epithelium in association with Gardner's syndrome. Figure 11 Reactive hyperplasia of retinal pigment epithelium secondary to a retained metallic intraocular foreign body. Figure 12 Peripheral form of combined hamartoma of the retina and retinal pigment epithelium. Figure 13 A choroidal haemangioma. response to a retained metallic intraocular foreign body. ${ }^{118}$ One patient was referred with a raised pigmented mass close to the optic disc, which was thought to be a possible choroidal melanoma (Figure 11). The patient gave a history of a metallic foreign body entering his eye some years earlier and subsequent ultrasonography and plain radiology confirmed the presence of retained foreign body. Occasionally, reactive hyperplasia of the RPE may occur in the absence of any precipitating stimulus. ${ }^{119-121}$

\section{Combined hamartoma of the retina and retinal pigment epithelium}

In 1973 Gass introduced the term: combined hamartoma of the retina and retinal pigment epithelium (CHR-RPE) to describe a series of patients with focal tumour-like lesions of the neuro-retina and RPE. ${ }^{122}$ Previous reports had described similar lesions as hyperplasia of the retinal pigment epithelium ${ }^{123}$ or hamartomas of the retina. ${ }^{124}$ Combined hamartomas of the retina and retinal pigment epithelium are rare with only about 100 cases reported in the literature. ${ }^{125,126}$ The clinical appearances of these lesions are quite diverse and differ depending on the location of the lesion within the fundus. ${ }^{127}$ McLean ${ }^{127}$ characterized them into either juxtapapillary or peripheral lesions noting that the location appeared to influence their appearance and presentation. He noted that juxtapapillary lesions appear to occur more frequently in males who presented with visual loss between 20 to 45 years of age. In contrast, peripheral lesions tended to occur at an earlier age and showed no sex predilection. Subsequent reports have not confirmed these relationships. ${ }^{125}$

Nevertheless, the ophthalmoscopic appearances of lesions occurring in these two locations do appear to differ. Juxtapapillary lesions present as a solitary raised mass adjacent to or overlying the optic disc which is variably pigmented and contains varying degrees of abnormal blood vessels and white or gray fibro-glial material. Peripheral lesions appear as an elevated vascular ridge concentric to the optic disc, which is associated with dragging or distortion of the proximal retinal vessels (Figure 12). Vitreous haemorrhage, retinal exudation and occasionally retinal detachment may occur in association with CHR-RPE. ${ }^{125,128}$

Although some patients with CHR-RPE may have normal vision or minimally reduced vision, others may suffer a dramatic loss of vision, which usually occurs as a result of the direct involvement of the optic disc, papillo-macular bundle or fovea. Occasionally, visual loss may occur as a result of vitreous or retinal 
haemorrhage, or epiretinal membrane formation and macular hole. ${ }^{129}$ In the majority of cases the lesion remains unchanged throughout life. In exceptional cases slow progressive enlargement may be observed. ${ }^{130}$ The lesion is almost always unilateral; to date the author is only aware of seven reported cases of bilateral involvement. ${ }^{131-137}$

Whilst most cases of CHR-RPE appear to be sporadic, there is increasing evidence that these hamartomas may be associated with both neurofibromatosis types 1 and 2 (NF-1, NF-2). Palmer et $a l^{133}$ reported two children with multiple café-au-lait spots and CHR-RPEs and Destro et al ${ }^{135}$ reported a case of a 25-year-old female with NF-1 who had a retinal mass, which was believed to be a CHR-RPE. They also reported a further case of a 3-year-old boy with presumed bilateral CHR-RPEs and multiple caféau-lait spots in whom the definite diagnosis of NF-1 or NF-2 was yet to be established. Tsai and $\mathrm{O}^{\prime}$ Brien $^{138}$ recently reported a case of a 6-year-old child with unilateral visual loss, which was the presenting sign of her NF-1. Whilst the association between NF-1 and CHR-RPEs is limited to sporadic case reports, there is now good evidence to support the association between CHR-RPEs and NF-2. In 1977 Cotlier reported a case of 'café-au-lait spots' in the fundus of a patient with neurofibromatsis. ${ }^{139}$ In retrospect this is probably the first documented case of CHR-RPE occurring in association with NF-2. Since then there have been a number of reports supporting this association. ${ }^{134,140-147}$ It is interesting to note that epiretinal membranes, retinal hamartomas and CHR-RPEs have all been reported in association with NF-2 ${ }^{143}$ and it is probable that they represent a spectrum of a continuous disease process. ${ }^{125}$

\section{Non-pigmented lesions}

\section{Primary choroidal tumours}

Choroidal haemangioma Haemangiomas of the choroid may be either circumscribed or diffuse in nature. Diffuse haemangiomas occur almost exclusively in association with facial naevus flammeus or with some other manifestation of the Sturge-Weber syndrome ${ }^{148}$ and as such they do not pose a diagnostic problem. Circumscribed choroidal haemangiomas, on the other hand, almost always occur as an isolated finding and are not associated with a cutaneous or systemic condition. ${ }^{149}$ However, the author has recently seen three cases of an apparently circumscribed choroidal haemangioma in association with the Sturge-Weber syndrome. One of these cases has been reported in the literature. ${ }^{150}$ A further case has also been reported by Scott $e t a l^{151}$ and given the relative infrequency of circumscribed choroidal haemangiomas and naevus flammeus it would suggest that occasionally these two conditions may be associated.

In contrast to diffuse lesions, circumscribed choroidal haemangiomas may be a cause of considerable diagnostic difficulty and are one of the lesions most commonly mistaken for a choroidal melanoma. Shields found in a series of 400 pseudomelanomas that $32(8 \%)$ were choroidal haemangiomas. ${ }^{4}$ In a recent survey of the author's own practice, choroidal haemangiomas accounted for $6.7 \%$ of the pseudomelanomas (manuscript in preparation) and were indeed the most frequently misdiagnosed condition after naevi and IMLs. Circumscribed haemangiomas may present at any age, are most frequently diagnosed in the third and fourth decades; and affect both white and nonwhite individuals. ${ }^{149}$ Choroidal haemangiomas were found to occur equally in males and females in one large series ${ }^{148}$ whereas, males were found to be affected in over $70 \%$ of cases in another study of similar size. ${ }^{149}$

Circumscribed choroidal haemangiomas have a curious predilection for the posterior choroid with over $85 \%$ occurring within $3 \mathrm{~mm}$ of the fovea. ${ }^{149}$ Because of this they typically present with visual loss, induced hypermetropia or metamorphopsia. Extrafoveal lesions may be asymptomatic and be detected on routine ophthalmoscopic examination. On fundoscopy they appear as a raised reddish-orange, dome-shaped mass, which may blend almost imperceptibly into the surrounding choroid (Figure 13). The overlying retinal pigment epithelium is almost always abnormal: often being replaced by foci of pale sclerotic tissue and/or small clumps of black granular pigment. Neuro-retinal abnormalities are also common and range from a subtle microcystic change to a large, shifting, secondary retinal detachment. Progressive enlargement of circumscribed choroidal haemangiomas is uncommon; Shields et al reported a case where a significant increase in size occurred over a 10-year period, the eye eventually being enucleated because an amelanotic melanoma could not be excluded. ${ }^{152}$ Histological examination suggested that the increase in size was due to vascular engorgement within the tumour rather than by cell multiplication.

Medlock $e t ~ a l^{153}$ reported five cases of growth that occurred over a long time interval. Whilst these lesions do not appear to change greatly in size under normal circumstances, they may undergo significant changes during pregnancy. Pitta $e t ~ a l^{154}$ reported a case of a 30year-old female who presented with reduced vision when 5 months pregnant; a choroidal haemangioma 
was found to be the cause of her visual loss. Following delivery the tumour and associated retinal detachment both regressed. The author has observed three similar cases where significant enlargement of a choroidal haemangioma and/or the associated retinal detachment accompanied an otherwise normal pregnancy (manuscript submitted for publication). In one case the accumulation of subretinal fluid was so extensive that the patient underwent an elective caesarian section at 37 weeks. There followed a dramatic resolution of the retinal detachment. It is probable that the altered haemodynamics experienced during pregnancy leads to engorgement of the tumour and an increased transudation of fluid.

In most instances the diagnosis of a circumscribed choroidal haemangioma is made on clinical grounds. Careful examination of the tumour with a 90-diopter lens is particularly valuable. Ancillary investigations are of some value in confirming the diagnosis. Some circumscribed choroidal haemangiomas have a characteristic appearance on fluorescein angiography: there is very early filling of the large vascular channels which gives a progressively hyperfluorescent irregular linear pattern. As the transit continues, these vascular channels leak dye into the tumour matrix to produce an intense diffuse fluorescence. The late angiograms often demonstrate intra-retinal fluorescence where the dye has leaked into the cystoid spaces within the retina.

Unfortunately, many haemangiomas do not exhibit this characteristic pattern and may be confused with some choroidal melanomas. Recent studies suggest that indocyanine green videoangiography may be of greater value in differentiating choroidal haemangiomas from melanomas. ${ }^{155,156}$ Specific features on indocyanine green angiography include: early hyperfluorescence followed by late hypofluorescence and a hyperfluorescent rim. ${ }^{156}$ A scan ultrasonography typically shows a high initial spike at the tumour surface followed by relatively high internal reflectivity within the tumour mass. On B scan ultrasonography the lesion usually appears as a dome-shaped mass with a relatively high internal signal, which lacks acoustic hollowness or choroidal excavation, which may be observed in similar sized melanomas. Once again, atypical lesions occur; Spraul et al recently reported a case of a choroidal haemangioma that was mushroom or collar stud-shaped and exhibited choroidal excavation. ${ }^{157}$

Circumscribed choroidal haemangiomas, which are asymptomatic, may be managed simply by periodic observation. Symptomatic haemangiomas represent a serious therapeutic challenge. Traditionally argon laser photocoagulation over the tumour surface has been used in an attempt to reduce the leakage and aid the re-absorption of subretinal fluid. Unfortunately repeated treatments are often required and even then the long-term visual prognosis is poor. ${ }^{149,158}$ Anand et $a l^{149}$ found that although the visual acuity could be stabilized in 34 out of 64 patients (53\%), the level of visual acuity at the most recent consultation was less than $6 / 15$ in $72 \%$ of cases. Low dose external beam irradiation and plaque brachytherapy have also been used to treat these lesions. Schilling et al ${ }^{159}$ recently reported the results of using low dose external beam irradiation in the treatment of choroidal haemangiomas; they found that of the 36 cases of circumscribed haemangioma, complete resolution of subretinal fluid was achieved in 23 patients (63.8\%) and the vision was maintained or improved in 28 (77.8\%) patients. Zografos et al ${ }^{160}$ treated 54 patients with choroidal haemangiomas (48 circumscribed, 6 diffuse) using proton beam irradiation and found a resolution of the retinal detachment in all cases. The same group had previously reported the results of treatment of these lesions with Cobalt-60 brachytherapy ${ }^{161}$ and found that in all 41 cases there was reattachment of the retina and replacement of the tumour by a flat scar. Madreperla et al ${ }^{162}$ in a retrospective study of the treatment of circumscribed choroidal haemangiomas by photocoagulation, brachytherapy or external irradiation concluded that both forms of irradiation were an effective alternative to photocoagulation. We have recently reported the preliminary results of using indocyanine green enhanced transpupillary diode thermotherapy (TTT) in the treatment of circumscribed choroidal haemangiomas. ${ }^{163}$ We treated six patients and found that all the tumours regressed following therapy and that the vision improved by two or more lines in four patients. Two published case reports have also documented similar encouraging results following the use of TTT. ${ }^{164,165}$

Choroidal osteoma In 1978 Gass et al ${ }^{166}$ reported five cases of an osseous tumour arising in the juxtapapillary choroids of otherwise normal eyes of four young healthy females. In one patient the eye had been removed because a radioactive phosphorous (32P) uptake test suggested the diagnosis of an atypical amelanotic melanoma. The histological appearances of the lesion reported by both Gass et al ${ }^{166}$ and subsequently by Williams et al ${ }^{167}$ demonstrated that it was composed of mature bone with numerous interconnecting marrow spaces filled with loose connective tissue and thin-walled, dilated blood vessels. Normal osteoblasts, osteocytes and osteoclasts were present in the bony matrix. Subsequent reports 
have characterized the clinical features of this curious lesion. ${ }^{168}$ Choroidal osteomas occur most frequently in young healthy females in either the second or third decades of life. A recent study of a large cohort of patients noted that 31 of 36 patients (89\%) were female. ${ }^{169}$ The lesion may be bilateral in a quarter to one third of cases. There appears to be no racial predilection and although in most instances their occurrence is sporadic, several cases of a familial development have been reported. ${ }^{170-172}$ Interestingly, all the familial cases reported to date have been bilateral in origin. Furthermore, three of the seven affected individuals were male; a much higher proportion than occurs in apparently sporadic cases.

Clinically, the affected patient may be asymptomatic at presentation or have metamorphopsia or variable visual loss depending on the location of the lesion. ${ }^{168}$ Typically, the lesion appears as a round or ovoid, yellow or orange placoid subretinal juxta or peripapillary mass (Figure 14). Occasionally, the lesion involves the macular region and in these cases visual loss is usually significant. The surface of the lesion is frequently covered by multiple tufts of short vascular trunks that may stand out as linear silhouettes in the late phases of fluorescein angiography. In addition to these vessels, which represent the intrinsic vasculature of the osteoma, subretinal neovascular membranes occur and may lead to the development of subretinal fluid or haemorrhage. Aylward et al recently reported a long-term follow-up on a series of 36 patients with choroidal osteoma ${ }^{169}$ and found that the probability of developing choroidal neovascularization was $47 \%$ by 10 years and $56 \%$ by 20 years. In these cases haemorrhage may lead to subretinal fibrosis and scarring and severe visual loss if it arises beneath the fovea. ${ }^{169,172,173}$ Aylward et al calculated the probability for loss of visual acuity to $6 / 60$ or worse to be $58 \%$ by 10 years and $62 \%$ at 20 years. ${ }^{169}$ Progressive enlargement ${ }^{169,174-178}$ or even the development of an osteoma ${ }^{172,175}$ in a previously unaffected eye has been reported. Growth may occur in over $40 \%$ of cases if followed for long enough. ${ }^{169}$ Conversely, spontaneous decalcification ${ }^{179,180}$ or involution ${ }^{181}$ of a choroidal osteoma has also been observed.

In most cases, once the suspicion that a choroidal lesion may be an osteoma has been raised, the diagnosis can usually be established with the aid of one or two ancillary investigations. Ultrasonography is extremely useful; B scan ultrasonography demonstrates a minimally elevated, highly reflective choroidal mass with profound acoustic shadowing in the orbit. The reflectivity persists after attenuation of the sensitivity of the signal has rendered the other ocular tissues invisible. CT scans of the affected eye demonstrate a high-density plaque in the affected choroid. Curiously, MRI imaging does not show the typical negative bone image; instead the lesion appears as a hyper-intense signal on T1-weighted images and as an area of relative low intensity on T2-weighted images. The tumour enhances with gadolinium on T1-weighted scans. ${ }^{182}$ Recently, the optical coherence tomographic patterns of choroidal osteomas have been investigated. ${ }^{183}$ Two patterns were observed; multiple tracks of high reflectivity were noted posterior to the tumour and thick and irregular plate-like, high signal intensity areas were present in the choroid in the region of the tumour.

Most cases of choroidal osteoma once the diagnosis has been established can be managed by periodic observation. In cases where symptomatic subretinal neovascularization occurs laser photocoagulation has been used with varying success. ${ }^{169,172,184-187}$ One study found that only $25 \%$ of patients with choroidal neovascularization were successfully treated with laser photocoagulation. ${ }^{169}$ There is a solitary case report of laser photocoagulation for subretinal neovascularization apparently fortuitously leading to partial reabsorption of the osteoma. ${ }^{188}$

\section{Secondary choroidal neoplasms In 1984 Horner ${ }^{189}$} documented the first case of an intraocular metastasis and although, for many years, this was considered a rare event, it is now recognized that metastases are the most common intraocular malignancy. ${ }^{190-192}$ The precise incidence of intraocular metastases is difficult to establish; estimates based upon clinical studies differ significantly from autopsy studies. Figures derived from the latter are understandably greater, for many patients with occult metastases will be asymptomatic and too ill to undergo routine ophthalmoscopic examination. Moreover, in many cases the metastatic deposits will be microscopic and too small to be detected clinically. An early clinical study undertaken by Godtfredson in $1944^{193}$ found only six cases $(0.07 \%)$ out of 8712 patients referred for radiotherapy for the treatment of a metastatic carcinoma. Albert et al ${ }^{194}$ in 1967 found ophthalmoscopic evidence of intraocular metastases in five out of 213 (2.3\%) patients with known metastatic carcinoma. This increasing frequency probably reflects a combination of increasing survival and the introduction of the indirect ophthalmoscope in routine fundal examination. Bloch and Gartner in $1971^{190}$ reported the results of a large postmortem study of the eyes from patients dying from metastatic carcinoma. They found that out of 230 patients intraocular metastatic foci were found in 25 cases $(10.9 \%)$. In a prospective histopathological study of 716 eyes of patients who had malignant disease at the time 
of death, Nelson et al ${ }^{195}$ found ocular metastases in 52 patients $(7.3 \%)$. In a recent study Eliasssi-Rad et $a l^{192}$ compared the frequency of metastases found in eye bank specimens obtained between 1988 and 1993 with those obtained at autopsy between 1976 and 1980 . They found that of the eyes from 302 patients, which had not been used for transplantation, and were subsequently submitted for pathological examination, three $(1 \%)$ had a gross intra-ocular metastasis. In the autopsy group a total of 741 patients had died from a malignant disease and, of these, microscopic metastases were found in 93 cases (12.6\%). Ocular involvement was observed in 40 out of 115 (34.8\%) of patients dying from various forms of leukaemia, 14 out of 60 (23\%) patients with lymphoma and 25 out of 510 (5.1\%) patients dying from carcinoma. When comparing the eye with other target organs it would appear to be a relatively uncommon site for the development of metastases. In patients with disseminated disease, tissues such as the lung, brain, kidneys and bone are involved much more frequently. This might suggest that the eye is a relatively unfavorable site for metastases to develop. It is well recognized that the metastatic process is extremely complex and does not rely on the mere chance passage of tumour cells to target organs via the blood stream. There is a complex interaction between circulating tumour cells and the target tissue. ${ }^{196}$ Weiss ${ }^{197}$ calculated the metastatic efficiency index (MEI), which is an analytical method of comparing the propensities of different target sites for metastatic development, of intraocular tissues as targets for metastasis from primary cancers of the breast, lung and colo-rectum. He found that the calculated MEI values for the uvea, as a target site for metastases from these cancers was in fact the highest for any previously investigated cancer and target site. This suggests that the uvea is, in fact, an extremely favourable tissue to develop metastases.

Ferry and Font ${ }^{191}$ found that males and females were approximately equally affected by intraocular metastases; subsequent reports have indicated a definite female preponderance. ${ }^{73,198}$ Shields et $a l^{73}$ in a study of 420 patients found that $283(67 \%)$ were female. This bias can be attributed to the fact that breast carcinoma accounts for the majority of cases of intraocular metastases. Indeed, in this latter series the breast was the primary location in $47 \%$ of patients. Lung was the next most frequently involved site (21\%) followed by gastrointestinal tract (4\%), kidney (2\%), skin $(2 \%)$ and prostate $(2 \%)$. Interestingly, the primary site remained unknown in $17 \%$ of cases.

The choroid is the most frequent site for intraocular metastases: Shields et $a l^{73}$ found a total of 950 uveal metastases in a total of 420 patients and, of these, 838 $(88 \%)$ were located in the choroid. Ninety (9\%) metastases were located in the iris and only $22(2 \%)$ in the ciliary body. They found that the right and left eyes were equally affected and that bilateral involvement occurred in $23.8 \%$ of patients and of these bilateral cases $64 \%$ were metastatic breast carcinomas. Solitary metastases were found in $71 \%$ of cases, with $12 \%$ of the eyes containing two lesions and $17 \%$ containing three or more.

Choroidal metastatic breast carcinomas typically appear as minimally elevated, cream or pale yellow lesions, which tend to blend imperceptibly into the surrounding choroid. The surface of the tumour is frequently covered with brown or golden clumps of retinal pigment epithelium, which may coalesce to form a reticular pattern (Figure 15). Occasionally, breast metastases may present as a large elevated solitary mass, although in the author's experience this is less common. Retinal detachment is common, particularly in the case of larger lesions. As stated previously these lesions are often multifocal and bilateral. Although fluorescein angiography is, in general, of little value in establishing the diagnosis it may reveal a more extensive lesion than was thought on ophthalmoscopy, or demonstrate further lesions, which were not apparent clinically.

Metastases derived from other sites usually present, in my experience as a pale cream, elevated domeshaped mass, which in many cases may resemble an amelanotic melanoma (Figure 16). Fine granularity of overlying RPE may be present on the tumour surface, but the pronounced reticular pattern seen on metastatic breast lesions is uncommon.

When confronted by a patient with typical multifocal and/or bilateral lesions and a prior history of neoplasia the diagnosis is straightforward. However, when presented with a patient who has a solitary amelanotic lesion and no prior history of malignancy, the diagnosis can be more challenging. Shields et $a l^{73}$ noted that approximately one third of patients with a uveal metastasis have no history of a primary cancer at the time of ocular diagnosis. In such cases a careful search for an occult primary lesion prior to treatment is mandatory. Whilst non invasive techniques such as fluorescein angiography or ultrasonography may be of value in distinguishing choroidal metastases from certain other lesions, I have found them of little value in differentiating them from amelanotic melanomas. In such circumstances fine needle aspiration biopsy may be of considerable value in assisting with the diagnosis. 

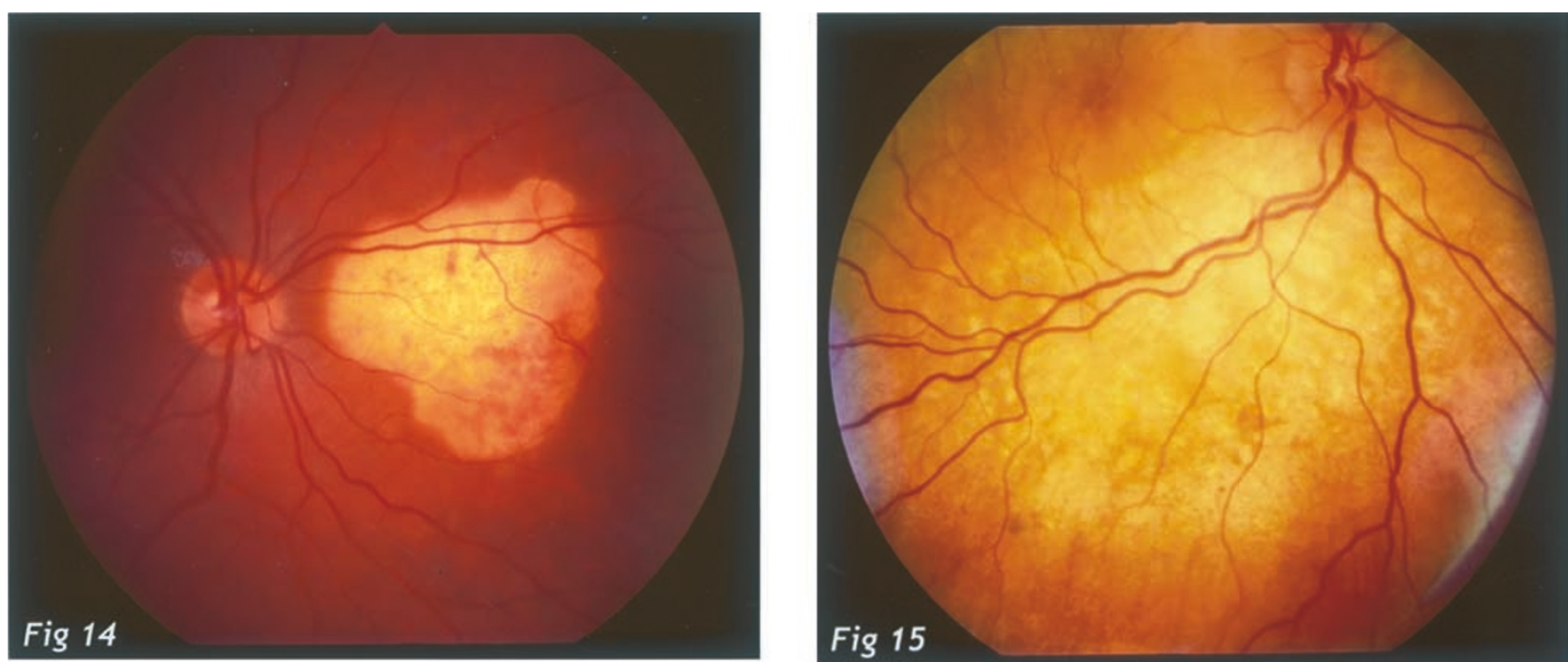

Fig 15
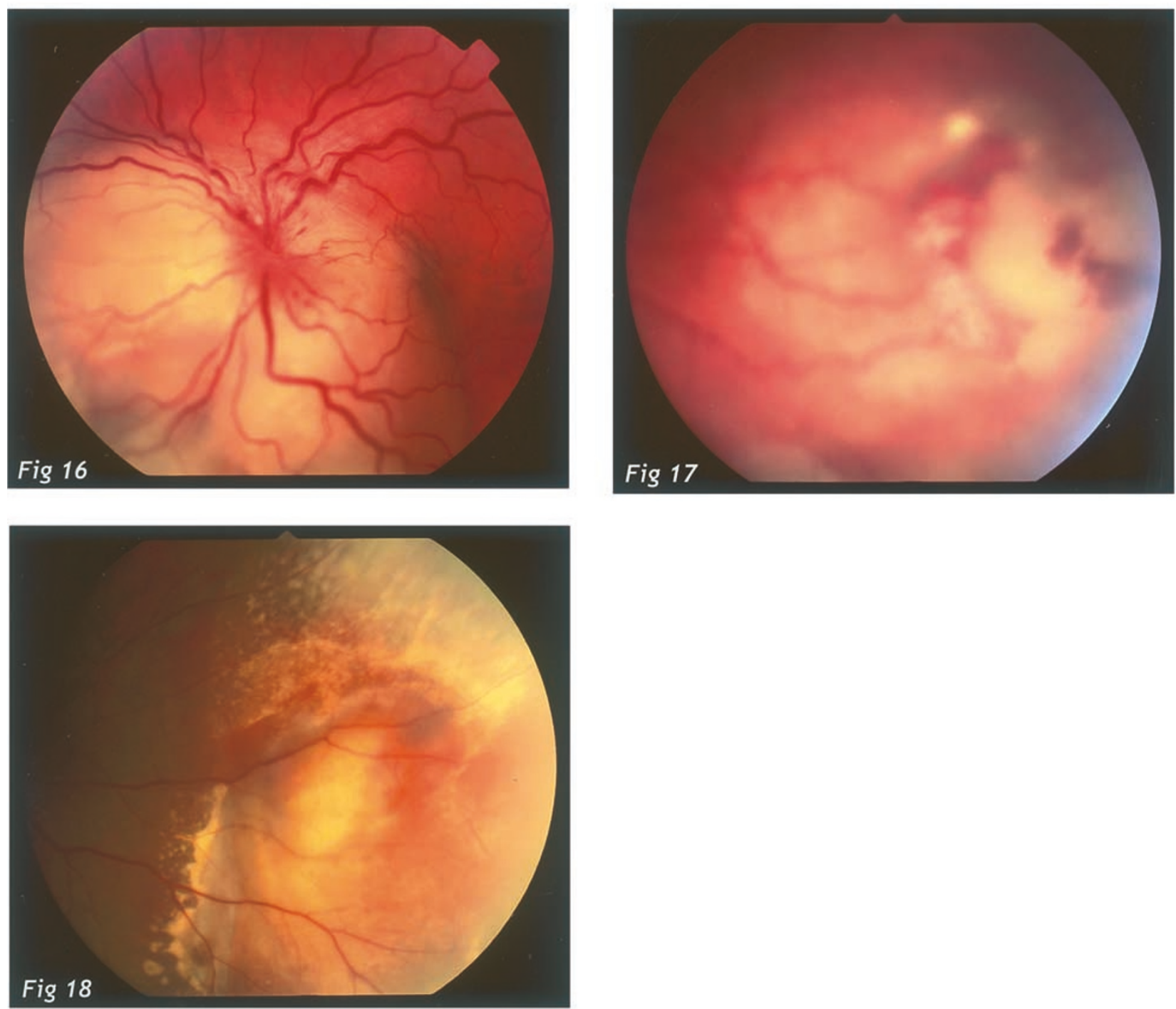


\section{Vascular lesions}

\section{Vasoproliferative tumours of the retina (presumed acquired retinal haemangiomas)}

In 1982 Baines et al reported the presence of peripheral telangiectatic nodules, associated with a proliferation of a posterior fibro-cellular membrane in seven eyes of five patients. ${ }^{199}$ They noted that the nodules resembled angiomas but lacked the dilated feeder vessels seen in Von Hippel-Lindau disease. The following year Shields et al described 12 patients with non-familial unilateral solitary vascular lesions of the neuro-retina. ${ }^{200}$

Although these tumours again resembled the angiomas seen in Von Hippel-Lindau syndrome they differed in a number of respects: they presented at an older age (the mean age at diagnosis was 58 years), there was no family history or associated systemic problems, they were unilateral, solitary, and there was no macular exudation and in keeping with the previous report they also lacked tortuous feeder vessels supplying the lesion. In the absence of histological verification, the authors coined the term presumed acquired retinal haemangioma (PARH) to describe the lesion. Similar lesions have been reported in the literature both prior and subsequent to these reports using a variety of terms which, to some extent, delayed the recognition of this condition as a distinct disease entity. Such lesions have been termed: peripheral retinal angiomas, ${ }^{201}$ angioma-like mass ${ }^{202}$ or lesion ${ }^{203,204}$ retinal angiomatous mass, ${ }^{205}$ retinal angiomatosis in the elderly, ${ }^{206}$

haemangioma-like mass ${ }^{207}$ or lesion ${ }^{208}$ and peripheral retinal telangiectasia. ${ }^{209}$ Shields et al in $1995^{210}$ reported a large series of 103 affected patients, and renamed the condition as a vasoproliferative retinal tumour. This term has now gained wide acceptance. In this latter study, the lesions were classified as idiopathic (74\%) or secondary to a preexisting ocular disease $(26 \%)$ and morphologically were found to be solitary $(87 \%)$, multiple $(6 \%)$ or diffuse $(6 \%)$. Patients with idiopathic tumours had an average age of 40 at presentation (range 11-76 years). Males and females appeared equally affected and there appeared no predilection for either eye. Interestingly the lesion appears to have a curious affinity for the inferior retina and was found in the infero-temporal quadrant in almost half of the cases. Clinically, the lesion appears as a raised vascular lesion in the peripheral retina (Figure 17). Intra or

Figures 14-18 Figure 14 An osseous choristoma. Figure 15 A choroidal deposit of metastatic breast carcinoma. Figure 16 A peripapillary deposit of metastatic carcinoma of the bronchus. Figure 17 A vasoproliferative tumour of the retina. Figure 18 An eccentric disciform (peripheral) choroidal neovascularization. subretinal exudation is present in over $80 \%$ of cases. A secondary retinal detachment is present in approximately half of the cases and a vitreous haemorrhage is found in nearly one quarter of the patients. Macular changes are common and include preretinal fibrosis and oedema. The lesions are sometimes associated with a mildly dilated feeding arteriole and draining vein, these do not however have the dimensions of the vessels seen supplying von Hippel-Lindau angiomas.

Secondary lesions, were morphologically similar to the primary lesions, but were associated with a variety of ocular conditions including: intermediate uveitis, retinitis pigmentosa, toxoplasmosis and toxocariasis. Marked retinal pigment epithelial proliferation was found adjacent to the vasoproliferative lesion in over half of the cases and was present in all the cases that were associated with retinitis pigmentosa. A recent study has confirmed the finding of vasoproliferative retinal tumours associated with hypertrophic retinal scars secondary to presumed congenital toxoplasmosis. ${ }^{211}$

Ancillary investigations such as fluorescein angiography are often difficult due to the frequent peripheral nature of these lesions. When angiograms of sufficient quality are obtained they show a connection between the retinal feeder vessels and a rich capillary network within the tumour which are often telangiectactic. ${ }^{212}$ Several vasoproliferative retinal tumours have now been examined histologically and have shown that the lesions are composed of a mixture of slender spindle-shaped cells which stained positively for GFAP, suggesting a glial origin together with a vascular component which comprised a fine capillary network together with larger dilated blood vessels, characterized by marked hyalinization of their walls. ${ }^{212-214}$ Although the pathogenesis of vasoproliferative tumours remains unclear, it is probable that a variety of disease processes can initiate a proliferation of retinal glial cells and blood vessels to produce a discernible tumour mass. ${ }^{212} \mathrm{~A}$ variety of modalities have been used to treat vasoproliferative retinal tumours including: laser photocoagulation, ${ }^{210}$ cryotherapy $^{210-212}$ plaque brachytherapy,,$^{210,212}$ and vitrectomy. ${ }^{210,215}$

\section{Age related choroidal neovascularization}

Age related disciform lesions either macular or peripheral may be mistaken for an amelanotic melanoma and accounted for $6.5 \%$ of pseudomelanomas referred to the author's unit. Whilst small macular lesions usually pose no diagnostic difficulty; large, elevated, peripheral lesions can be a 
considerable cause of confusion. In general, these lesions can be differentiated from amelanotic melanomas by the presence of extensive subretinal exudation (Figure 18). Although a small amount of exudation may occasionally be observed at the base of a melanoma, it rarely, if ever attains the same degree as seen surrounding a disciform lesion. Some amount of subretinal haemorrhage either fresh or denatured is almost invariably present overlying the surface of a disciform lesion. Vitreous haemorrhage may occur, which can in some cases, obscure fundal detail. Again, vitreous bleeding may develop in the presence of a choroidal melanoma; however, this frequently arises from tumours that have a small herniation of tissue through Bruch's membrane. ${ }^{216}$ Careful ultrasonography may detect these small herniations facilitating the diagnosis. In contrast, disciform lesions do not typically produce such breaches in Bruch's membrane, but rather produce dome-shaped lesions with high internal reflectivity. In cases where ultrasonography is unhelpful, it is often prudent to merely observe the patient for a short period, in the expectation that the haemorrhage will clear allowing sufficient visualization of the lesion to establish the diagnosis. In cases where the haemorrhage persists, pars plana vitrectomy accompanied by trans-vitreal fine needle biopsy may be of considerable value in establishing the diagnosis. ${ }^{217}$ In cases where the ocular media is clear, fluorescein angiography can be utilized to confirm the diagnosis. Disciform lesions demonstrate hyperfluorescence corresponding to the areas of active neovascularization and profound hypofluorescence in areas of subretinal haemorrhage. However, caution must be exercised in interpreting the angiography results, for occasionally disciform lesions may be observed on the surface of choroidal melanomas that may provide a diagnostic pitfall for the unwary.

\section{Inflammatory lesions}

\section{Posterior scleritis}

Patients with posterior scleritis can present with large elevated lesions, which may simulate an amelanotic choroidal melanoma. ${ }^{218}$ In many instances, the presence of pain coupled with either a prior history of anterior scleritis or evidence of active anterior segment involvement would strongly point to the diagnosis of posterior scleritis. Occasionally, however, a patient presents with a painless posterior scleritis in the absence of any anterior segment involvement. Finger et al reported a case of a 66-year-male who presented with a large painless intraocular mass in his right eye which was enucleated and found upon histological examination to contain grossly thickened necrotic sclera. ${ }^{219}$ Recently, Demirci et al ${ }^{220}$ reported a case of a 41-year-old asymptomatic woman with a $7.5 \mathrm{~mm}$ thick intraocular mass, which was initially thought to be a malignant melanoma. Subsequent evaluation, including scleral biopsy confirmed the lesion to be nodular posterior scleritis. Careful evaluation can usually differentiate these lesions from true neoplasms. Scleritic nodules are orange in colour and are frequently associated with choroidal folds, which radiate from the lesion. Ultrasonography, may confirm a thickening of the sclera and presence of oedema in the adjacent tenons capsule. Moreover, posterior scleritis will usually show a marked response to therapy with either systemic non-steroidal anti-inflammatory agents or systemic corticosteroids in contrast to uveal melanomas, which will usually fail to demonstrate any response to therapy.

In contrast, occasionally, patients with a choroidal melanoma may present with symptoms suggestive of posterior scleritis. Yap et al ${ }^{221}$ reported three cases where the patients presented with clinical features of scleritis and where the ultimate diagnosis was that of a choroidal melanoma. Interestingly, in all three cases the lesion demonstrated at least a partial response to corticosteroid therapy. More recently, Bhagat et al ${ }^{222}$ reported a case of acute scleritis and scleral necrosis associated with a choroidal melanoma.

\section{Conclusions}

There are many lesions that may be mistaken for a choroidal melanoma. It is vital that such lesions are correctly diagnosed in order that, not only inappropriate treatment be avoided, but also appropriate treatment not be withheld.

\section{Acknowledgements}

I am indebted to a number of individuals in preparing this lecture: Rhona Jacques, Lesley Hinchliffe, Michelle Evans and Paul Rundle, my colleagues in the ocular oncology service in Sheffield for their constant help and support. Chris Mody, Laura Ferguson and Michele Best for their skill in constantly photographing the impossible. Robin Farr for his considerable technical assistance. John Talbot, Michael Nelson and Andy Parsons for all their encouragement over the years. My fellow consultant colleagues, who over the years, have been kind enough to refer me these interesting patients. Finally, my wife Sharon, who has had to endure me during the long weeks preceding this lecture. 


\section{References}

1 Ferry A. Lesions mistaken for malignant melanoma of the posterior uvea. Arch Ophthalmol 1964; 72: 463-469.

2 Shields JA, McDonald PR. Improvements in the diagnosis of posterior uveal melanomas. Arch Ophthalmol 1974; 91: 259-264.

3 Anonymous. Accuracy of diagnosis of choroidal melanomas in the Collaborative Ocular Melanoma Study. COMS report No. 1 (published erratum appears in Arch Ophthalmol 1990; 108: 1708). Arch Ophthalmol 1990; 108: 1268-1273.

4 Shields JA, Augsburger JJ, Brown GC, Stephens RF. The differential diagnosis of posterior uveal melanoma. Ophthalmology 1980; 87: 518-522.

5 Sumich P, Mitchell P, Wang JJ. Choroidal nevi in a white population: the Blue Mountains Eye Study. Arch Ophthalmol 1998; 116: 645-650.

6 Hale PN, Allen RA, Straatsma BR. Benign melanomas (nevi) of the choroid and ciliary body. Arch Ophthalmol 1965; 74: 532-538.

7 Ganley JP, Comstock GW. Benign nevi and malignant melanomas of the choroid. Am J Ophthalmol 1973; 76: 1925.

8 Albers EC. Benign melanomas of the choroid and their malignant transformation. Am J Ophthalmol 1940; 23: 779-783.

9 Gass JD. Problems in the differential diagnosis of choroidal nevi and malignant melanomas. The XXXIII Edward Jackson Memorial Lecture. Am J Ophthalmol 1977; 83: 299-323.

10 Macllwaine Wat, Anderson B, Jr, Klintworth GK. Enlargement of a histologically documented choroidal nevus. Am J Ophthalmol 1979; 87: 480-486.

11 Naumann GHK, Naumann LR. Pigmented nevi of the choroid: clinical study of secondary changes in the overlying tissues. Trans Am Acad Ophthalmol Otolaryngol 1971; 75: 110-122.

12 Deutsch TA, Jampol LM. Large druse-like lesions on the surface of choroidal nevi. Ophthalmology 1985; 92: 73-76.

13 Fournier GA, Albert DM, Wagoner MD. Choroidal halo nevus occurring in a patient with vitiligo. Surv Ophthalmol 1984; 28: 671-672.

14 Maumenee ETAE. Clinical study of choroidal nevi. Arch Ophthalmol 1959; 62: 196-202.

15 Naumann G, Zimmerman LE, Yanoff M. Visual field defect associated with choroidal nevus. Am J Ophthalmol 1966; 62: 914-917.

16 Flindall RJ, Drance SM. Visual field studies of benign choroidal melanomata. Arch Ophthalmol 1969; 81: 41-44.

17 Gonder JR, Augsburger JJ, McCarthy EF, Shields JA. Visual loss associated with choroidal nevi. Ophthalmology 1982; 89: 961-965.

18 Madison Slusher M, Weaver RG. Presumed choroidal naevi and sensory retinal detachment. Br J Ophthalmol 1977; 61: 414-416.

19 Callanan DG, Lewis ML, Byrne SF, Gass JD. Choroidal neovascularization associated with choroidal nevi. Arch Ophthalmol 1993; 111: 789-794.

20 Sisley K, Rennie IG, Cottam DW, Potter AM, Potter CW, Rees RC. Cytogenetic findings in six posterior uveal melanomas: involvement of chromosomes 3, 6 and 8 . Genes, Chromosomes \& Cancer 1990; 2: 205-209.

21 Prescher G, Bornfeld N, Becher R. Nonrandom chromosomal abnormalities in primary uveal melanoma. J Nat Cancer Inst 1990; 82: 1765-1769.

22 Horsthemke B, Prescher G, Bornfeld N, Becher R. Loss of chromosome 3 alleles and multiplication of chromosome 8 alleles in uveal melanoma. Genes, Chromosomes \& Cancer 1992; 4: 217-221.

23 Sisley K, Cottam DW, Rennie IG, Parsons MA, Potter AM, Potter CW et al. Non-random abnormalities of chromosomes 3, 6 and 8 associated with posterior uveal melanoma. Genes, Chromosomes \& Cancer 1992; 5: 197200.

24 Prescher G, Bornfeld N, Horsthemke B, Becher R Chromosomal aberrations defining uveal melanoma of poor prognosis [letter]. Lancet 1992; 339: 691-692.

25 Sisley K, Rennie IG, Parsons MA, Jacques R, Hammond DW, Bell SM et al. Abnormalities of chromosomes 3 and 8 in posterior uveal melanoma correlate with prognosis. Genes, Chromosomes \& Cancer 1997; 19: 22-28.

26 Sisley K, Parsons MA, Garnham J, Potter AM, Curtis D, Rees RC et al. Association of specific chromosome alterations with tumour phenotype in posterior uveal melanoma. Br J Cancer 2000; 82: 330-338.

27 Zimmerman LEG, Garron LK. Melanocytoma of the optic disc. Int Ophthalmol Clin 1962; 2: 431-440.

28 Joffe L, Shields JA, Osher RH, Gass JD. Clinical and follow-up studies of melanocytomas of the optic disc. Ophthalmology 1979; 86: 1067-1083.

29 Osher RH, Shields JA, Layman PR. Pupillary and visual field evaluation in patients with melanocytoma of the optic disc. Arch Ophthalmol 1979; 97: 1096-1099.

30 Usui T, Shirakashi M, Kurosawa A, Abe H, Iwata K. Visual disturbance in patients with melanocytoma of the optic disk. Ophthalmologica 1990; 201: 92-98.

31 Archdale TW, Magnus DE. Melanocytoma of the optic disc. I Am Opt Assoc 1993; 64: 98-103.

32 Zimmerman LE. Melanocytes, melanocytic nevi, and melanocytoma. Invest Ophthalmol Vis Sci 1965; 4: 11-41.

33 Takahashi T, Isayama Y, Okuzawa I. Unusual case of melanocytoma in optic disk. Jap J Ophthalmol 1984; 28: 171-175.

34 Garcia-Arumi J, Salvador F, Corcostegui B, Mateo C. Neuroretinitis associated with melanocytoma of the optic disk. Retina 1994; 14: 173-176.

35 Lehman LJ, Hohberger GG, Buettner H, Campbell RJ. Necrotic melanocytoma of the choroid in a 2-year-old child. J Ped Ophthalmol Strabis 1997; 34: 40-43.

36 Croxatto JO, Ebner R, Crovetto L, Morales AG. Angle closure glaucoma as initial manifestation of melanocytoma of the optic disc. Ophthalmology 1983; 90: 830-834.

37 Yamaguchi K, Shiono T, Mizuno K. Pigment deposition in the anterior segment caused by melanocytoma of the optic disc. Ophthalmologica 1987; 194: 191-193.

38 Mansour AM, Zimmerman L, La Piana FG, Beauchamp GR. Clinicopathological findings in a growing optic nerve melanocytoma. Br J Ophthalmol 1989; 73: 410-415.

39 Lauritzen K, Augsburger JJ, Timmes J. Vitreous seeding associated with melanocytoma of the optic disc. Retina 1990; 10: 60-62.

40 Frangieh GT, el Baba F, Traboulsi EI, Green WR. Melanocytoma of the ciliary body: presentation of four cases and review of nineteen reports. Surv Ophthalmol 1985; 29: 328-334

41 Scheie HG, Yanoff M. Pseudomelanoma of the ciliary 
body. Report of a patient. Arch Ophthalmol 1967; 77: 811813.

42 Biswas J, D'Souza C, Shanmugam MP. Diffuse melanotic lesion of the iris as a presenting feature of ciliary body melanocytoma: report of a case and review of the literature. Surv Ophthalmol 1998; 42: 378-382.

43 Bhorade AM, Edward DP, Goldstein DA. Ciliary body melanocytoma with anterior segment pigment dispersion and elevated intraocular pressure. J Glaucoma 1999; 8: 129-133.

44 Thomas CI, Purnell EW. Ocular melanocytoma. Am Ophthalmol 1969; 67: 79-86.

45 Barker-Griffith AE, McDonald PR, Green WR. Malignant melanoma arising in a choroidal magnacellular nevus (melanocytoma). Can J Ophthalmol 1976; 11: 140-146.

46 Roth AM. Malignant change in melanocytomas of the uveal tract. Surv Ophthalmol 1978; 22: 404-412.

47 Cialdini AP, Sahel JA, Jalkh AE, Weiter JJ, Zakka K, Albert DM. Malignant transformation of an iris melanocytoma. A case report. Graefes Arch Clin Exp Ophthalmol 1989; 227: 348-354.

48 Shields JA, Shields CL, Eagle RC, Jr, Lieb WE, Stern S. Malignant melanoma associated with melanocytoma of the optic disc. Ophthalmology 1990; 97: 225-230.

49 Shetlar DJ, Folberg R, Gass JD. Choroidal malignant melanoma associated with a melanocytoma. Retina 1999; 19: 346-349.

50 Shields JA, Shields CL, Eagle RC, Jr, Santos C, Singh AD. Malignant melanoma arising from a large uveal melanocytoma in a patient with oculodermal melanocytosis. Arch Ophthalmol 2000; 118: 990-993.

51 Gass JD, Gieser RG, Wilkinson CP, Beahm DE, Pautler SE. Bilateral diffuse uveal melanocytic proliferation in patients with occult carcinoma. Arch Ophthalmol 1990; 108: $527-533$

52 Machemer R. [On the pathogenesis of the flat malignant melanoma]. Klinische Monatsblatter fur Augenheilkunde 1966; 148: 641-652.

53 Ryll DL, Campbell RJ, Robertson DM, Brubaker SJ. Pseudometastatic lesions of the choroid. Ophthalmology 1980; 87: 1181-1186.

54 Barr CC, Zimmerman LE, Curtin VT, Font RL. Bilateral diffuse melanocytic uveal tumors associated with systemic malignant neoplasms. A recently recognized syndrome. Arch Ophthalmol 1982; 100: 249-255.

55 Prusiner PE, Butler A, Yavitz EQ, Stern WH. Metastatic adenocarcinoma presenting as bilateral blindness. Ann Ophthalmol 1983; 15: 653-656.

56 Mullaney J, Mooney D, O'Connor M, McDonald GS. Bilateral ovarian carcinoma with bilateral uveal melanoma. Br J Ophthalmol 1984; 68: 261-267.

57 Prause JU, Jensen OA, Eisgart F, Hansen U, Kieffer M. Bilateral diffuse malignant melanoma of the uvea associated with large cell carcinoma, giant cell type, of the lung. Case report of a newly described syndrome. Ophthalmologica 1984; 189: 221-228.

58 de Wolff-Rouendaal D. Bilateral diffuse benign melanocytic tumours of the uveal tract. A clinicopathological study. Int Ophthalmol 1985; 7: 149160.

59 Filipic M, Ambler JS. Bilateral diffuse melanocytic uveal tumours associated with systemic malignant neoplasm. Aust NZ J Ophthalmol 1986; 14: 293-299.

60 Tsukahara S, Wakui K, Ohzeki S. Simultaneous bilateral primary diffuse malignant uveal melanoma: case report with pathological examination. Br J Ophthalmol 1986; 70: 33-38.

61 Margo CE, Pavan PR, Gendelman D, Gragoudas E. Bilateral melanocytic uveal tumors associated with systemic non-ocular malignancy. Malignant melanomas or benign paraneoplastic syndrome? Retina 1987; 7: 137141.

62 Rohrbach JM, Roggendorf W, Thanos S, Steuhl KP, Thiel HJ. Simultaneous bilateral diffuse melanocytic uveal hyperplasia. Am J Ophthalmol 1990; 110: 49-56.

63 Leys AM, Dierick HG, Sciot RM. Early lesions of bilateral diffuse melanocytic proliferation. Arch Ophthalmol 1991; 109: 1590-1594.

64 Gass JD, Glatzer RJ. Acquired pigmentation simulating Peutz-Jeghers syndrome: initial manifestation of diffuse uveal melanocytic proliferation. Br J Ophthalmol 1991; 75: 693-695.

65 Borruat FXO-GP, Uffer S, Othenin-Girard B, Regli F, Hurlimann J. Natural history of diffuse uveal melanocytic proliferation. Ophthalmology 1992; 99: 1698 1704.

66 Mooy CM, de Jong PT, Strous C. Proliferative activity in bilateral paraneoplastic melanocytic proliferation and bilateral uveal melanoma. Br J Ophthalmol 1994; 78: 483484.

67 Murphy MA, Hart WM, Jr, Olk RJ. Bilateral diffuse uveal melanocytic proliferation simulating an arteriovenous fistula. J Neuro-Ophthalmol 1997; 17: 166169.

68 Donovan JT, Prefontaine M, Gragoudas ES. Blindness as a consequence of a paraneoplastic syndrome in a woman with clear cell carcinoma of the ovary. Gynecol Oncol 1999; 73: 424-429.

69 Margo CE, Lowery RL, Kerschmann RL. Lack of p53 protein immunoreactivity in bilateral diffuse uveal melanocytic proliferation. Retina 1997; 17: 434-436.

70 Tobal K, Warren W, Cooper CS, McCartney A, Hungerford J, Lightman S. Increased expression and mutation of p53 in choroidal melanoma. $\mathrm{Br} J$ Cancer 1992; 66: 900-904.

71 Jay V, Yi Q, Hunter WS, Zielenska M. p53 expression in uveal malignant melanomas. Pathology 1996; 28: 306-308.

72 Kishore K, Ghazvini S, Char DH, Kroll S, Selle J. p53 gene and cell cycling in uveal melanoma. Am J Ophthalmol 1996; 121: 561-567.

73 Shields CL, Shields JA, Gross NE, Schwartz GP, Lally SE. Survey of 520 eyes with uveal metastases. Ophthalmology 1997; 104: 1265-1276.

74 Gunduz K, Shields JA, Shields CL, Eagle RC, Jr. Cutaneous melanoma metastatic to the vitreous cavity. Ophthalmology 1998; 105: 600-605.

75 Fishman ML, Tomaszewski MM, Kuabara T. Malignant melanoma of the skin metastatic to the eye. Frequency in autopsy series. Arch Ophthalmol 1976; 94: 1309-1311.

76 Greven CM, Slusher MM, Stanton C, Yeatts RP. Cutaneous malignant melanoma metastatic to the choroid. Arch Ophthalmol 1991; 109: 547-549.

77 Ramaesh K, Marshall JW, Wharton SB, Dhillon B. Intraocular metastases of cutaneous malignant melanoma: a case report and review of the literature. Eye 1999; 13: 247-250.

78 Letson AD, Davidorf FH. Bilateral retinal metastases 
from cutaneous malignant melanoma. Arch Ophthalmol 1982; 100: 605-607.

79 Spraul CW, Martin DF, Hagler WS, Grossniklaus HE. Cytology of metastatic cutaneous melanoma to the vitreous and retina. Retina 1996; 16: 328-332.

80 Shields JA, Shields CL (eds). Intraocular Tumors: a Text and Atlas. WB Saunders Company: Philadelphia, 1992, $\mathrm{p} 235$.

81 Reese AB, Jones IS. Benign melanomas of the retinal pigment epithelium. Am J Ophthalmol 1956; 42: 207-212.

82 Buettner $\mathrm{H}$. Congenital hypertrophy of the retinal pigment epithelium (RPE). A non-tumorous lesion. Mod Prob Ophthalmol 1974; 12: 528-535.

83 Purcell JJ, Shields JA. Hypertrophy with hyperpigmentation of the retinal pigment epithelium. Arch Ophthalmol 1975; 102: 1122-1126.

84 Gass JD. Focal congenital anomalies of the retinal pigment epithelium. Eye 1989; 3: 1-18.

85 Chamot L, Zografos L, Klainguti G. Fundus changes associated with congenital hypertrophy of the retinal pigment epithelium. Am J Ophthalmol 1993; 115: 154-161.

86 Cleary PE, Gregor Z, Bird AC. Retinal vascular changes in congenital hypertrophy of the retinal pigment epithelium. Br J Ophthalmol 1976; 60: 499-503.

87 Cohen SL, Quentel G, Guiberteau B, Cosas GJ. Retinal vascular changes in congenital hypertrophy of the retinal pigment epithelium. Ophthalmology 1993; 100: 471-474.

88 Norris DA, Cleasby GW. An unusual case of congenital hypertrophy of the retinal pigment epithelium. Arch Ophthalmol 1976; 94: 1910-1911.

89 Boldrey EE, Schwartz A. Enlargement of congenital hypertrophy of the retinal pigment epithelium. Am J Ophthalmol 1982; 94: 64-66.

90 Shields JA, Shields CL, Singh AH. Aquired tumors arising from congenital hypertrophy of the Retinal Pigment Epithelium. Arch Ophthalmol 2000; 118: 637-641.

91 Haggitt RC, Reid BJ. Hereditary gastrointestinal polyposis syndromes. Am J Surg Pathol 1986; 10: 871887.

92 Bodmer WF, BCJ, Bodmer J, Bussey HJR, Ellis A Gorman $\mathrm{P}$ et al. Location of the gene for familial adenomatous polyposis on chromosome 5. Nature 1987, 328: 614-616.

93 Blair NP, Trempe CL. Hypertrophy of the retinal pigment epithelium associated with Gardner's syndrome. Am J Ophthalmol 1980; 90: 661-667.

94 Traboulsi EI, Maumenee IH, Krush AJ, Alcorn D, Giardiello FM, Burt RW et al. Congenital hypertrophy of the retinal pigment epithelium predicts colorectal polyposis in Gardner's syndrome. Arch Ophthalmol 1990; 108: $525-526$

95 Shields JA, Shields CL, Shah PG, Pastore DJ, Imperiale SM Jr. Lack of association among typical congenital hypertrophy of the retinal pigment epithelium, adenomatous polyposis, and Gardner syndrome. Ophthalmology 1992; 99: 1709-1713.

96 Pang CP, Keung JW, Tang NL, Fan DS, Lau JW, Lam DS. Congenital hypertrophy of the retinal pigment epithelium and APC mutations in two Chinese families with familial adenomatous polyposis. Eye 2000; 14: 1822.

97 Caspari R, Olschwang S, Friedl W, Mandl M, Boisson C, Boker $\mathrm{T}$ et al. Familial adenomatous polyposis: desmoid tumours and lack of ophthalmic lesions (CHRPE) associated with APC mutations beyond codon 1444 Hum Mol Genet 1995; 4: 337-340.

98 Olschwang S, Tiret A, Laurent-Puig P, Muleris M, Parc $R$, Thomas G. Restriction of ocular fundus lesions to a specific subgroup of APC mutations in adenomatous polyposis coli patients. Cell 1993; 75: 959-968.

99 Reck AC, Bunyan D, Eccles D, Humphry R. The presence of congenital hypertrophy of the retinal pigment epithelium in a subgroup of patients with adenomatous polyposis coli mutations. Eye 1997; 11: 298-300.

100 Ziskind A, Kitze MJ, Grobbelaar JJ. The relationship between congenital hypertrophy of the retinal pigment epithelium (CHRPE) and germline mutations in the adenomatous polyposis coli (APC) gene. Ophthal Genet 1999; 20: 53-56.

101 Garner A. Tumours of the retinal pigment epithelium. Br J Ophthalmol 1970; 54: 715-723.

102 Finger PT, McCormick SA, Davidian M, Walsh JB Adenocarcinoma of the retinal pigment epithelium: a diagnostic and therapeutic challenge. Graefes Arch Clin Exp Ophthalmol 1996; 234: S22-S27.

103 Shields JA, Shields CL, Gunduz K, Eagle RC Jr. Neoplasms of the retinal pigment epithelium: the 1998 Albert Ruedemann, Sr, memorial lecture, Part 2. Arch Ophthalmol 1999; 117: 601-608.

104 Griffith J. On a rare form of primary intraocular melanoma. Trans Ophthalmol Soc UK 1894; 14: 715-723.

105 Martens M. Eine primare bosartige epitheliale Geschwulst des Augeninnern beim Erwachsenen. Arch Augenheilkd 1921; 89: 1-22.

106 Schuster H. Retinoepithelioma malignum pigmentosum. Virchows Arch Anat Physiol Klin Med 1928; 269: 97-104.

107 Bietti G. Ueber ein vom Pigmentepithel ausgehendes Melanokarzinom des Bulbus und der Orbita. Klin Monatsbl Augenheilk 1931; 87: 459-486.

108 Tso MO, Albert DM. Pathological condition of the retinal pigment epithelium. Neoplasms and nodular non-neoplastic lesions. Arch Ophthalmol 1972; 88: 27-38.

109 Shields JA, Eagle RC Jr, Shields CL. Adenoma of nonpigmented ciliary epithelium with smooth muscle differentiation. Arch Ophthalmol 1999; 117: 117-119.

110 Ronne G. Malignant tumour originated from the pigment epithelium of the retina. Acta Ophthalmologica 1945; 23: 382-383

111 Fair JR. Tumors of the RPE. Am J Ophthalmol 1958; 45: 495-504.

112 Minckler D, Allen AW Jr. Adenocarcinoma of the retinal pigment epithelium. Arch Ophthalmol 1978; 96: 22522254.

113 Ramahefasolo S, Soubrane G, Dhermy P, Godel V, Regenbogen L, Coscas G. Adenocarcinoma of retinal pigment epithelium [published erratum appears in $\mathrm{Br}$ ] Ophthalmol 1988; 72: 80]. Br J Ophthalmol 1987; 71: 516520

114 Fan JT, Robertson DM, Cambell RJ. Clinicopathological correlation of a case of adenocarcinoma of the retinal pigment epithelium. Am J Ophthalmol 1995; 119: 243-245.

115 Loose IA, Jampol LE, O'Grady R. Pigmented adenoma mimicking a juxtapapillary melanoma. Arch Ophthalmol 1999; 117: 120-122.

116 Shields JA, Eagle RC, Jr, Barr CC, Shields CL, Jones DE. Adenocarcinoma of retinal pigment epithelium arising 
from a juxtapapillary histoplasmosis scar. Arch Ophthalmol 1994; 112: 650-653.

117 Shields JA, Melki T, Shields CL, Eagle RC, Singh AD. Epipapillary adenoma of retinal pigment epithelium. Retina 2001; 21: 76-77.

118 Cunliffe I, Singh A, Mody C, Innes J, Rennie I. Retained intraocular foreign body simulating choroidal melanoma. A report of two cases. Germ J Ophthalmol 1993; 2: 416418.

119 Spiers F, Jenson OA. Pseudo-epitheliomatous hyperplasia of the retinal pigment epithelium. Acta Ophthalmologica 1963; 41: 722-727.

120 Stow NM. Hyperplasia of the pigment epithelium of the retina simulating a neoplasm. Trans Am Acad Ophthalmol Otolaryngol 1949; 53: 674-677.

121 Olsen TW, Frayer WC, Myers FL, Davis MD, Albert DM. Idiopathic reactive hyperplasia of the retinal pigment epithelium. Arch Ophthalmol 1999; 117: 50-54

122 Gass JD. An unusual hamartoma of the pigment epithelium and retina simulating choroidal melanoma and retinoblastoma. Trans Am Ophthalmol Soc 1973; 71: 171-183; discussions 184-185.

123 Theobald GD, Floyd G, Kirk HQ. Hyperplasia of the retinal pigment epithelium. Am J Ophthalmol 1958; 45: 235-240.

124 Cardell BS, Starbuck MJ. Juxtapapillary hamartoma of the retina. Br J Ophthalmol 1961; 45: 672-677.

125 Schachat AP, Shields JA, Fine SL, Sanborn GE, Weingeist TA, Valenzuela RE et al. Combined hamartomas of the retina and retinal pigment epithelium. Ophthalmology 1984; 91: 1609-1615.

126 Font RL, Moura RA, Shetlar DJ, Martinez JA, Mcpherson AR. Combined hamartoma of sensory retina and retinal pigment epithelium. Retina 1989; 9: 302-311.

127 McLean EB. Hamartoma of the retinal pigment epithelium. Am J Ophthalmol 1976; 82: 227-231.

128 Kahn D, Goldberg MF, Jednock N. Combined retinalretina pigment epithelial hamartoma presenting as a vitreous hemorrhage. Retina 1984; 4: 40-43.

129 Mason JO, Kleiner R. Combined hamartoma of the retina and retinal pigment epithelium associated with epiretinal membrane and macular hole. Retina 1997; 17: 160-162.

130 Rosenberg PR, Walsh JB. Retinal pigment epithelial hamartoma-unusual manifestations. Br J Ophthalmol 1984; 68: 439-42.

131 Laqua H, Wessing A. Congenital retino-pigment epithelial malformation, previously described as hamartoma. Am J Ophthalmol 1979; 87: 34-42.

132 Gass JDM. Stereoscopic Atlas of Macular DiseasesDiagnoses and Treatment. Mosby: St Louis, 1987, p 624W.

133 Palmer ML, Carney MD, Combs JL. Combined hamartomas of the retinal pigment epithelium and retina. Retina 1990; 10: 33-36.

134 Good WV, Erodsky MC, Edwards MS, Hoyt WF. Bilateral retinal hamartomas in neurofibromatosis type 2 . Br J Ophthalmol 1991; 75: 190.

135 Destro M, D'Amico DJ, Gragoudas ES, Brockhurst RJ, Pinnolis MK, Albert DM et al. Retinal manifestations of neurofibromatosis. Diagnosis and management. Arch Ophthalmol 1991; 109: 662-666.

136 Meyer JH, Witschel H. Bilateral combined hamartoma of the retina and retinal pigment epithelium. $\mathrm{Br} J$ Ophthalmol 1996; 80: 577-578.
137 Blumenthal EZ, Papamichael G, Merlin S. Combined hamartoma of the retina and retinal pigment epithelium: a bilateral presention. Retina 1998; 18: 557-559.

138 Tsai P, O'Brein JO. Combined hamartoma of the retina and retinal pigment epithelium as the presenting sign of neurofibromatosis-1. Ophthalmic Surg Lasers 2000; 31 145-147.

139 Cotlier E. Cafe-au-lait spots in the fundus in neurofibromatosis. Arch Ophthalmol 1977; 95: 1990-1992.

140 Kaye LD, Rothner AD, Beauchamp GR, Meyers SM, Estes ML. Ocular findings associated with neurofibromatosis type II. Ophthalmology 1992; 99: 14241429.

141 Bouzas EA, Parry DM, Eldridge R, Kaiser-Kupfer MI. Familial occurrence of combined pigment epithelial and retinal hamartomas associated with neurofibromatosis 2 . Retina 1992; 12: 103-107.

142 Parry DM, Eldridge R, Kaiser-Kupfer MI, Bouzas EA, Pikus A, Patronas N. Neurofibromatosis 2 (NF2): clinical characteristics of 63 affected individuals and clinical evidence for heterogeneity. Am J Med Genet 1994; 52 450-461.

143 Ragge NK, Baser ME, Klein J, Nechiporuk A, Sainz J, Pulst SM et al. Ocular abnormalities in neurofibromatosis 2. Am J Ophthalmol 1995; 120: 634-641.

144 Meyers SM, Gutman FA, Kaye LD, Rothner AD. Retinal changes associated with neurofibromatosis 2. Trans Am Ophthalmol Soc 1995; 93: 245-252; discussion 252-257.

145 Rettele GA, Brodsky MC, Merin LM, Teo C, Glasier CM. Blindness, deafness, quadriparesis, and a retinal malformation: the ravages of neurofibromatosis 2. Surv Ophthalmol 1996; 41: 135-141.

146 Ragge NK, Baser ME, Riccardi VM, Falk RE. The ocular presentation of neurofibromatosis 2. Eye 1997; 11: 12-18.

147 Baser ME, Kluwe L, Mautner VF. Germ-line NF2 mutations and disease severity in neurofibromatosis type 2 patients with retinal abnormalities (letter). Am J Hum Genet 1999; 64: 1230-1233.

148 Witschel H, Font RL. Hemangioma of the choroid. A clinicopathologic study of 71 cases and a review of the literature. Surv Ophthalmol 1976; 20: 415-431.

149 Anand R, Augsburger JJ, Shields JA. Circumscribed choroidal hemangiomas. Arch Ophthalmol 1989; 107: 1338-1342.

150 Cheung D, Grey R, Rennie I. Circumscribed choroidal haemangioma in a patient with Sturge Weber syndrome (letter). Eye 2000; 14: 238-240.

151 Scott IU, Alexandrakis G, Cordahi GJ, Murray TG. Diffuse and circumscribed choroidal hemangiomas in a patient with Sturge-Weber syndrome. Arch Ophthalmol 1999; 117: 406-407.

152 Shields JA, Stephens RF, Eagle RC Jr, Shields CL, De Potter P. Progressive enlargement of a circumscribed choroidal hemangioma. A clinicopathologic correlation. Arch Ophthalmol 1992; 110: 1276-1278.

153 Medlock RD, Augsburger JJ, Wilkinson CP, Cox MS Jr, Gamel JW, Nicholl J. Enlargement of circumscribed choroidal hemangiomas. Retina 1991; 11: 385-388.

154 Pitta C, Bergen R, Littwin S. Spontaneous regression of a choroidal hemangioma following pregnancy. Ann Ophthalmol 1979; 11: 772-774.

155 Piccolino FC, Borgia L, Zinicola E. Indocyanine green angiography of circumscribed choroidal hemangiomas. Retina 1996; 16: 19-28. 
156 Arevalo JF, Shields CL, Shields JA, Hykin PG, De Potter $P$. Circumscribed choroidal hemangioma: characteristic features with indocyanine green videoangiography. Ophthalmology 2000; 107: 344-350.

157 Spraul CW, Kim D, Fineberg E, Grossniklaus HE. Mushroom-shaped choroidal hemangioma. Am J Ophthalmol 1996; 122: 434-436.

158 Sanborn GE, Augsburger JJ, Shields JA. Treatment of circumscribed choroidal hemangiomas. Ophthalmology 1982; 89: 1374-1380.

159 Schilling H, Sauerwein W, Lommatzsch A, Friedrichs W, Brylak S, Bornfeld N et al. Long-term results after low dose ocular irradiation for choroidal haemangiomas. $\mathrm{Br} J$ Ophthalmol 1997; 81: 267-273.

160 Zografos L, Egger E, Bercher L, Chamot L, Munkel G. Proton beam irradiation of choroidal hemangiomas. $\mathrm{Am}$ J Ophthalmol 1998; 126: 261-268.

161 Zografos L, Bercher L, Chamot L, Gailloud C, Raimondi $\mathrm{S}$, Egger E. Cobalt-60 treatment of choroidal hemangiomas. Am J Ophthalmol 1996; 121: 190-199.

162 Madreperla SA, Hungerford JL, Plowman PN, Laganowski HC, Gregory PT. Choroidal hemangiomas: visual and anatomic results of treatment by photocoagulation or radiation therapy. Ophthalmology 1997; 104: 1773-1778. discussion 1779.

163 Kamal A, Watts AR, Rennie IG. Indocyanine green enhanced transpupillary thermotherapy of circumscribed choroidal haemangioma. Eye 2000; 14: 701-705.

164 Rapizzi E, Grizzard WS, Capone A Jr. Transpupillary thermotherapy in the management of circumscribed choroidal hemangioma. Am J Ophthalmol 1999; 127: 481482.

165 Othmane IS, Shields CL, Shields JA, Gunduz K, Mercado G. Circumscribed choroidal hemangioma managed by transpupillary thermotherapy. Arch Ophthalmol 1999; 117: 136-137.

166 Gass JD, Guerry RK, Jack RL, Harris G. Choroidal osteoma. Arch Ophthalmol 1978; 96: 428-435.

167 Williams AT, Font RL, Van Dyk HJ, Riekhof FT. Osseous choristoma of the choroid simulating a choroidal melanoma. Association with a positive 32P test. Arch Ophthalmol 1978; 96: 1874-1877.

168 Shields CL, Shields JA, Augsburger JJ. Choroidal osteoma. Surv Ophthalmol 1988; 33: 17-27.

169 Aylward GW, Chang TS, Pautler SE, Gass JD. A longterm follow-up of choroidal osteoma. Arch Ophthalmol 1998; 116: 1337-1341.

170 Cunha SL. Osseous choristoma of the choroid. A familial disease. Arch Ophthalmol 1984; 102: 1052-1054.

171 Noble KG. Bilateral choroidal osteoma in three siblings. Am J Ophthalmol 1990; 109: 656-660.

172 Eting E, Savir H. An atypical fulminant course of choroidal osteoma in two siblings. Am J Ophthalmol 1992; 113: $52-55$.

173 Kelinske M, Weinstein GW. Bilateral choroidal osteomas. Am J Ophthalmol 1981; 92: 676-680.

174 Augsburger JJ, Shields JA, Rife CJ. Bilateral choroidal osteoma after nine years. Can J Ophthalmol 1979; 14: 281284.

175 Gass JD. New observations concerning choroidal osteomas. Int Ophthalmol 1979; 1: 71-84.

176 Trimble SN, Schatz H. Choroidal osteoma after intraocular inflammation. Am J Ophthalmol 1983; 96: 759764.
177 Shields JA, Shields CL, de Potter P, Belmont JB Progressive enlargement of a choroidal osteoma. Arch Ophthalmol 1995; 113: 819-820.

178 Mizota A, Tanabe R, Adachi-Usami E. Rapid enlargement of choroidal osteoma in a 3-year-old girl. Arch Ophthalmol 1998; 116: 1128-1129.

179 Trimble SN, Schatz H, Schneider GB. Spontaneous decalcification of a choroidal osteoma. Ophthalmology 1988; 95: 631-634

180 Trimble SN, Schatz H. Decalcification of a choroidal osteoma. Br J Ophthalmol 1991; 75: 61-63.

181 Buettner H. Spontaneous involution of a choroidal osteoma (letter). Arch Ophthalmol 1990; 108: 1517-1578.

182 DePotter P, Shields JA, Shields CL, Rao VM. Magnetic resonance imaging in choroidal osteoma. Retina 1991; 11: 221-223.

183 Ide T, Nobuyuki O, Hayashi A, Yamamoto S, Nakagawa Y, Nagae $\mathrm{Y}$ et al. Optical coherence tomography patterns of choroidal osteoma. Am J Ophthalmol 2000; 130.

184 Avila MP, El-Markabi H, Azzolini C, Jalkh AE, Burns D, Weiter JJ. Bilateral choroidal osteoma with subretinal neovascularization. Ann Ophthalmol 1984; 16: 381-385.

185 Burke JF Jr, Brockhurst RJ. Argon laser photocoagulation of subretinal neovascular membrane associated with osteoma of the choroid. Retina 1983; 3: 304-307.

186 Grand MG, Burgess DB, Singerman LJ, Ramsey J Choroidal osteoma. Treatment of associated subretinal neovascular membranes. Retina 1984; 4: 84-89.

187 Morrison DL, Magargal LE, Ehrlich DR, Goldberg RE, Robb-Doyle E. Review of choroidal osteoma: successful krypton red laser photocoagulation of an associated subretinal neovascular membrane involving the fovea. Ophthal Surg 1987; 18: 299-303.

188 Rose SJ, Burke JF, Brockhurst RJ. Argon laser photoablation of a choroidal osteoma. Retina 1991; 11 224-228.

189 Horner F. Carcinoma der dura mater exophthalmus. Klin Monatsbl Augenheilkd 1864; 2: 186-190.

190 Bloch RS, Gartner S. The incidence of ocular metastatic carcinoma. Arch Ophthalmol 1971; 85: 673-675.

191 Ferry AP, Font RL. Carcinoma metastatic to the eye and orbit. I. A clinicopathologic study of 227 cases. Arch Ophthalmol 1974; 92: 276-286.

192 Eliassi-Rad B, Albert DM, Green WR. Frequency of ocular metastases in patients dying of cancer in eye bank populations. Br J Ophthalmol 1996; 80: 125-128.

193 Godtfredson E. On the frequency of secondary carcinoma in the choroid. Arch Ophthalmol 1944; 22: 394400

194 Albert DM, Rubenstein RA, Scheie HG. Tumor metastasis to the eye. I. Incidence in 213 adult patients with generalized malignancy. Am J Ophthalmol 1967; 63: 723-726.

195 Nelson CC, Hertzberg BS, Klintworth GK. A histopathologic study of 716 unselected eyes in patients with cancer at the time of death. Am J Ophthalmol 1983; 95: 788-793

196 Fidler IJ. Recent concepts of cancer metastasis and their implications for therapy. Cancer Treat Rep 1984; 68: 193198

197 Weiss L. Analysis of the incidence of intraocular metastasis. Br J Ophthalmol 1993; 77: 149-151.

198 Stephens RF, Shields JA. Diagnosis and management of 
cancer metastatic to the uvea: a study of 70 cases. Ophthalmology 1979; 86: 1336-1349.

199 Baines P, Hiscott P, McLeod D. Posterior nonvascularized proliferative extraretinopathy and peripheral nodular retinal telangiectasis. Trans Ophthalmol Soc UK 1982; 102: 487-491.

200 Shields JA, Decker WL, Sanborn GE, Augsburger JJ, Goldberg RE. Presumed acquired retinal hemangiomas. Ophthalmology 1983; 90: 1292-1300.

201 Henkind P, Morgan G. Peripheral retinal angioma with exudative retinopathy in adults (Coat's lesion). $\mathrm{Br} \mathrm{J}$ Ophthalmol 1966; 50: 2-11.

202 Barr CC, Rice TA, Michels RG. Angioma-like mass in a patient with retrolental fibroplasia. Am J Ophthalmol 1980; 89: 647-650.

203 Galinos SO, Smith TR, Brockhurst RJ. Angioma-like lesion in hemoglobin sickle cell disease. Ann Ophthalmol 1979; 11: 1549-1552.

204 Laatikainen L, Immonen I, Summanen P. Peripheral retnal angiomalike lesion and macular pucker. Am J Ophthalmol 1989; 108: 563-566.

205 Gottlieb F, Fammartino JJ, Stratford TP, Brockhurst RJ. Retinal angiomatous mass. A complication of retinal detachment surgery. Retina 1984; 4: 152-157.

206 Schmitz-Valckenberg P, Meyer-Schwickerath G. Retinal angiomatosis in the aged. Ber Zusammenkunft Dtsch Ophthalmol Ges 1977; 74: 205-208.

207 Campochiaro PA, Conway BP. Hemangiomalike masses of the retina. Arch Ophthalmol 1988; 106: 1409-1413.

208 Medlock RD, Shields JA, Shields CL, Yarian DL, Beyrer CR. Retinal hemangioma-like lesions in eyes with retinitis pigmentosa. Retina 1990; 10: 274-277.

209 Laqua H, Wessing A. Peripheral retinal telangiectasis in adults simulating a vascular tumor or melanoma. Ophthalmology 1983; 90: 1284-1291.

210 Shields CL, Shields JA, Barrett J, De Potter P. Vasoproliferative tumors of the ocular fundus. Classification and clinical manifestations in 103 patients Arch Ophthalmol 1995; 113: 615-623.
211 Lafaut BA, Meire FM, Leys AM, Dralands G, De Laey JJ. Vasoproliferative retinal tumors associated with peripheral chorioretinal scars in presumed congenital toxoplasmosis. Graefes Arch Clin Exp Ophthalmol 1999; 237: 1033-1038.

212 Heimann H, Bornfeld N, Vij O, Coupland SE, Bechrakis $\mathrm{NE}$, Kellner $\mathrm{U}$ et al. Vasoproliferative tumours of the retina. Br J Ophthalmol 2000; 84: 1162-1169.

213 Smeets MH, Mooy CM, Baarsma GS, Mertens DE, Van Meurs JC. Histopathology of a vasoproliferative tumor of the ocular fundus. Retina 1998; 18: 470-472.

214 Irvine F, O'Donnell N, Kemp E, Lee WR. Retinal vasoproliferative tumors: surgical management and histological findings. Arch Ophthalmol 2000; 118: 563-569.

215 McDonald HR, Schatz H, Johnson RN, Abrams GW, Brown GC, Brucker AJ et al. Vitrectomy in eyes with peripheral retinal angioma associated with traction maculer detachment. Ophthalmology 1996; 103: 329-335.

216 Cunliffe IA, Rennie IG. Choroidal melanoma presenting as vitreous haemorrhage. Eye 1993; 7: 711-713.

217 Cohen VM, Dinakaran S, Parsons MA, Rennie IG. Transvitreal fine needle aspiration biopsy: the influence of intraocular lesion size on diagnostic biopsy result. Eye 2001; 15: 143-147.

218 Benson WE, Shields JA, Tasman W, Crandall AS. Posterior scleritis. A cause of diagnostic confusion. Arch Ophthalmol 1979; 97: 1482-1486.

219 Finger PT, Perry HD, Packer S, Erdey RA, Weisman GD, Sibony PA. Posterior scleritis as an intraocular tumour. Br J Ophthalmol 1990; 74: 121-122.

220 Demirci H, Shields CL, Honavar SG, Shields JA, Bardenstein DS. Long-term follow-up of giant nodular posterior scleritis simulating choroidal melanoma. Arch Ophthalmol 2000; 118: 1290-1292.

221 Yap EY, Robertson DM, Buettner H. Scleritis as an initial manifestation of choroidal malignant melanoma. Ophthalmology 1992; 99: 1693-1697.

222 Bhagat S, Ramaesh K, Wharton SB, Dhillon B. Spontaneous acute scleritis and scleral necrosis in choroidal malignant melanoma. Eye 1999; 13: 793-795. 